\title{
KOMITMEN ORGANISASIONAL DAN ORGANIZATIONAL CITIZENSHIP BEHAVIOR (OCB) SEBAGAI PEMEDIASI PADA PENGARUH GAYA KEPEMIMPINAN TRANSFORMASIONAL TERHADAP KINERJA PEGAWAI
}

( Studi pada Dinas Pertanian dan Kehutanan Kabupaten Rembang )

\author{
Prima Kartika Sari \\ Euis Soliha \\ Alumni Pascasarjana \\ Dosen Fakultas Ekonomika dan Bisnis \\ Universitas Stikubank Semarang \\ Email: soliha.euis@gmail.com
}

\begin{abstract}
This study aimed to analyze the effect of transformational leadership style to the organizational commitment, transformational leadership style to organizational citizenship behavior, organizational commitment on organizational citizenship behavior, organizational commitment to employee performance, transformational leadership style on employee performance and organizational citizenship behavior on employee performance. The sample used in this research is census method, the number of respondents was 103 employees at Dinas Pertanian dan Kehutanan Kabupaten Rembang. Data testing techniques used include test the validity of factor analysis, reliability test with Cronbach alpha formula, multiple regression analysis to validate the research hypothesis and test the mediation. From the test results show the transformational leadership style positive and significant effect on organizational commitment. Transformational leadership positive and significant effect on organizational citizenship behavior. Organizational commitment has no effect on organizational citizenship behavior. Organizational commitment positive and significant effect on employee performance. Transformational leadership style has no effect on employee performance. Organizational citizenship behavior positive and significant impact on employee performance. Organizational commitment and organizational citizenship behavior perfect mediate the effect of transformational leadership style on employee performance.
\end{abstract}

Keywords: Transformational Leadership Style, Organizational Commitment, Organizational Citizenship Behavior, Employee Performance.

\begin{abstract}
Abstrak
Penelitian ini bertujuan untuk menganalisis pengaruh gaya kepemimpinan trnsformasional terhadap komitmen organisasional, gaya kepemimpinan transformasional terhadap organizational citizenship behavior, komitmen organisasional terhadap organizational citizenship behavior, komitmen organisasional terhadap kinerja pegawai, gaya kepemimpinan transformasional terhadap kinerja pegawai, dan organizational citizenship behavior terhadap kinerja pegawai. Pengambilan sampel yang digunakan dalam penelitian ini adalah metode sensus, dengan jumlah responden sebanyak 103 orang pegawai di Dinas Pertanian dan Kehutanan Kabupaten Rembang. Teknik pengujian data yang digunakan meliputi uji validitas dengan analisis factor, uji reliabilitas dengan rumus alpha cronbach, analisis regresi berganda untuk membuktikan kebenaran hipotesis penelitian serta uji mediasi. Dari hasil pengujian menunjukkan gaya kepemimpinan transformasional berpengaruh positif dan signifikan terhadap komitmen organisasional. Gaya kepemimpinan transformasional berpengaruh positif dan signifikan terhadap organizational citizenship behavior. Komitmen
\end{abstract}


organisasional tidak berpengaruh terhadap organizational citizenship behavior. Komitmen organisasional berpengaruh positif dan signifikan terhadap kinerja pegawai. Gaya kepemimpinan transformasional tidak berpengaruh terhadap kinerja pegawai. Organizational citizenship behavior berpengaruh positif dan signifikan terhadap kinerja pegawai. Komitmen organisasional dan organizational citizenship behavior memediasi sempurna pengaruh gaya kepemimpinan transformasional terhadap kinerja pegawai.

Kata Kunci: Gaya Kepemimpinan Transformasional, Komitmen Organisasional, Organizational Citizenship Behavior, Kinerja Pegawai

\section{Pendahuluan}

Gaya kepemimpinan merupakan tulang punggung pengembangan organisasi karena tanpa kepemimpinan yang baik akan sulit untuk mencapai tujuan organisasi. Jika seorang pemimpin berusaha untuk mempengaruhi perilaku orang lain, maka orang tersebut perlu memikirkan gaya kepemimpinannya. Gaya kepemimpinan seorang pemimpin akan sangat mempengaruhi keberhasilan organisasi dalam mencapai tujuannya. Perilaku seorang pemimpin memiliki dampak yang besar, terkait dengan sikap bawahan, perilaku bawahan yang akhirnya pada kinerja.

Gaya kepemimpinan merupakan faktor penting dalam memberikan pengarahan kepada karyawan apalagi pada saat-saat sekarang ini di mana semua serba terbuka, maka kepemimpinan yang dibutuhkan adalah kepemimpinan yang bisa memberdayakan karyawannya. Kepemimpinan yang bisa menumbuhkan motivasi kerja karyawan adalah kepemimpinan yang bisa menumbuhkan rasa percaya diri para karyawan dalam menjalankan tugasnya masing-masing.

Peran pemimpin dalam segala situasi organisasi merupakan suatu faktor yang sangat strategis. Sampai saat ini penelitian-penelitian banyak dilakukan oleh ilmuwan sebagai salah satu upaya peningkatan efisiensi, dan efektivitas kerja organisasi. Pemimpin harus dapat menyampaikan visi dan misi organisasi secara persuasif dengan bahasa yang mudah dipahami dan dimengerti agar kinerjanya meningkat. Menurut Robbins (2008), bahwa keberhasilan suatu orgasnisasi dalam pencapaian tujuan melalui usaha menggerakkan orang lain dalam organisasi atau instansi tidak terlepas dari kapasitas, peranan, perilaku, dan karakteristik seseorang pimpinan.

Isu yang muncul terkait dengan otonomi daerah adalah bagaimana kemampuan Pemerintah Daerah dilihat dari sumber daya manusia aparatnya mampu mewadahi aktivitas pemerintahan, pelayanan publik dan pembangunan. Banyak daerah yang mengakui bahwa kemampuan sumber daya manusia aparaturnya masih perlu ditingkatkan. Pemerintah akhir akhir ini memberikan perhatian yang besar pada upaya-upaya peningkatan kompetensi aparatur dalam melaksanakan tugas-tugasnya, yakni memberikan pelayanan yang sebaikbaiknya kepada rakyat sesuai perannya sebagai abdi negara dan abdi masyarakat.

Kualitas dari pemimpin seringkali dianggap sebagai faktor terpenting dari keberhasilan atau kegagalan organisasi. Demikian juga keberhasilan atau kegagalan suatu organisasi baik yang berorientasi bisnis maupun publik, biasanya dipersepsikan sebagai keberhasilan atau kegagalan pemimpin. Begitu pentingnya peran pemimpin sehingga isu mengenai pemimpin menjadi faktor yang menarik perhatian para peneliti bidang perilaku keorganisasian. Hal ini akan membawa konsistensi bahwa setiap pemimpin berkewajiban memberikan perhatian yang sungguh-sungguh untuk membina, menggerakkan, mengarahkan semua potensi pegawai di lingkungannya agar terwujud volume dan beban kerja yang terarah pada tujuan

Beberapa fenomena yang dihadapi Dinas Pertanian dan Kehutanan Kabupaten Rembang yaitu: banyak para pegawai menganggap sukses organisasi tidak tergantung pada 
pimpinannya saja, tetapi keberadaan seorang pemimpin dalam organisasi tetap diperlukan sebagai penentu kebijakan; banyak para pegawai menganggap pelatihan kurang penting disebabkan menyita waktu tugas harian, padahal pelatihan berguna untuk meningkatkan kompetensi pegawai; distribusi pekerjaan yang ada tidak merata sehingga tingkat kinerja masing-masing pegawai tidak berimbang.

Permasalah dalam penelitian ini adalah sebagai berikut: apakah Gaya Kepemimpinan Transformasional berpengaruh terhadap Komitmen Organisasional pada Dinas Pertanian dan Kehutanan Kabupaten Rembang; apakah Gaya Kepemimpinan Transformasional berpengaruh terhadap Organizational Citizenship Behavior (OCB) pada Dinas Pertanian dan Kehutanan Kabupaten Rembang; apakah Komitmen Organisasional berpengaruh terhadap Organizational Citizenship Behavior OCB pada Dinas Pertanian dan Kehutanan Kabupaten Rembang; apakah Komitmen Organisasional berpengaruh terhadap Kinerja pada Dinas Pertanian dan Kehutanan Kabupaten Rembang; apakah Gaya Kepemimpinan Transformasional berpengaruh terhadap Kinerja pada Dinas Pertanian dan Kehutanan Kabupaten Rembang; apakah Organizational Citizenship Behavior (OCB) berpengaruh terhadap Kinerja pada Dinas Pertanian dan Kehutanan Kabupaten Rembang?

\section{Landasan Teori Dan Pengembangan Hipotesis}

\section{Kepemimpinan Transformasional}

Penggunaan pendekatan atau perspektif yang beragam atas kepemimpinan, selain melahirkan definisi kepemimpinan yang beragam juga melahirkan teori kepemimpinan yang beragam pula. Setiap pendekatan yang digunakan melahirkan berbagai macam teori kepemimpinan. Luthans (2006) mendefinisikan kepemimpinan sebagai sekelompok proses, kepribadian, pemenuhan, perilaku tertentu, persuasi, wewenang, pencapai tujuan, interaksi, perbedaan peran, inisiasi struktur, dan kombinasi dari dua atau lebih dari hal-hal tersebut.

Menurut Rivai dan Mulyadi (2012) kepemimpinan pada dasarnya: melibatkan orang lain, melibatkan distribusi kekuasaan yang tidak merata antara pemimpin dan anggota kelompok, menggerakkan kemampuan dengan menggunakan berbagai bentuk kekuasaan untuk mempengaruhi tingkah laku bawahan, dan menyangkut nilai. Empat sifat umum yang mempunyai pengaruh terhadap keberhasilan kepemimpinan organisasi, yaitu: (1) kecerdasan, (2) kedewasaan, (3) motivasi diri dan dorongan berprestasi, dan (4) sikap hubungan kemanusiaan.

James MacGregor Burns dalam Luthans (2006) mengidentifikasikan dua jenis kepemimpinan politis, yaitu transaksional hubungan pertukaran antara pemimpin dan pengikut, tetapi kepemimpinan transformasional lebih mendasarkan pada pergeseran nilai dan kepercayaan pemimpin, serta kebutuhan pengikutnya. Kepemimpinan transaksional adalah resep bagi keadaan seimbang, sedangkan kepemimpinan transformasional membawa keadaan menuju kinerja tinggi pada organisasi yang menghadapi tuntutan pembaruan dan perubahan. Karakteristik dan pendekatan pemimpin transaksional yaitu (Luthans, 2006)

1) Penghargaan kontingen, yaitu kontrak pertukaran penghargaan dengan usaha yang dikeluarkan, menjanjikan penghargaan untuk kinerja baik, mengakui pencapaian atau prestasi.

2) Manajemen berdasarkan kekecualian (aktif), yaitu:mengawasi dan mencari pelanggaran terhadap aturan dan standar, mengambil tindakan korektif.

3) Manajemen berdasarkan kekecualian (pasif), yaitu: intervensi hanya jika standar tidak dipenuhi.

4) Sesuka hati, yaitu: menghindari tanggung jawab, menghindari pengambilan keputusan. 
Adapun karakteristik dan pendekatan pemimpinan transformasional yaitu (Luthans,2006)

1) Karisma, yaitu: memberikan visi dan misi, memunculkan rasa bangga, mendapatkan respek dan kepercayaan.

2) Inspirasi, yaitu: mengkomunikasikan harapan tinggi, menggunakan simbol-simbol untuk memfokuskan usaha, mengekspresikan tujuan penting dalam cara yang sederhana.

3) Stimulasi intelektual, yaitu: menunjukkan inteligensi, rasional, pemecahan masalah secara hati-hati.

4) Memperhatikan individu, yaitu: menunjukkan perhatian terhadap pribadi, memperlakukan karyawan secara individual, melatih, menasehati.

\section{Komitmen Organisasional}

Komitmen organisasional didefinisikan oleh Durkin dan Bennet (1999) sebagai perasaan yang kuat dan erat dari seseorang terhadap tujuan dan nilai suatu organisasi dalam hubungannya dengan peran mereka terhadap upaya percapaian tujuan dan nilai-nilai tersebut. Luthans (2006) menyatakan bahwa komitmen organisasional merupakan sikap yang menunjukkan loyalitas karyawan dan merupakan proses berkelanjutan bagaimana seorang anggota organisasi mengepresikan perhatian mereka kepada kesuksesan dan kebaikan organisasinya. Lebih lanjut sikap loyalitas ini diindikasikan dengan tiga hal, yaitu (1) keinginan kuat seseorang untuk tetap menjadi anggota organisasinya; (2) kemauan untuk mengerahkan usahanya untuk organisasi; (3) keyakinan dan penerimaan yang kuat terhadap nilai-nilai dan tujuan organisasi. Komitmen organisasional akan membuat pekerja memberikan yang terbaik kepada organisasi tempat dia bekerja. Pekerja dengan komitmen yang tinggi akan lebih berorientasi pada kerja. pekerja yang memiliki komitmen organisasional tinggi akan cenderung senang membantu dan dapat bekerjasama.

Curtis dan Wright (2001) mengemukakan bahwa komitmen didefinisikan sebagai kekuatan identifikasi individu yang berada dalam sebuah organisasi. Jika seseorang memiliki komitmen untuk organisasi, ia akan memiliki identifikasi yang kuat dengan organisasi, ia akan memiliki identifikasi yang kuat dengan organisasi, memiliki nilai-nilai keanggotaan, setuju dengan tujuan dan sistem nilai, kemungkinan akan tetap di dalamnya, dan akhirnya, siap untuk bekerja keras demi organisasinya.

John dan Taylor (1999); Allen dan Meyer (1991); Sopiah (2008) mengemukakan suatu model anteseden (faktor-faktor yang mendahului) dari komitmen organisasional yaitu :

1) Karakteristik Pribadi

Beberapa karakteristik pribadi dianggap memiliki hubungan dengan komitmen organisasional yaitu usia dan masa kerja, tingkat pendidikan, status perkawinan, dan jenis kelamin.

2) Karakteristik Pekerjaan

Karakteristik pekerjaan merupakan posisi pekerjaan, yaitu karakteristik yang berkaitan dengan peran, self-employment, otonomi, jam kerja, tantangan dalam pekerjaan, serta tingkat kesulitan dalam pekerjaan.

3) Pengalaman Kerja

Pengalaman kerja dipandang sebagai suatu kekuatan sosialisasi utama yang mempunyai pengaruh penting dalam pembentukan ikatan psikologis dengan organisasi.

4) Karakteristik Struktural

Karakteristik struktural adalah karakteristik yang dikembangkan untuk meningkatkan komitmen individu kepada organisasi, meliputi kemajuan karis dan peluang promosi di 
masa yang akan datang, besar atau kecilnya organisasi, bentuk organisasi, dan tingkat pengendalian yang dilakukan organisasi terhadap karyawan.

Tett dan Meyer (1993); Meyer et al (2002); Karatus dan Aslan (2008); Luthans (2008); Aydogdu dan Asikgil (2011) mengemukakan tiga dimensi dari komitmen organisasional yaitu sebagai berikut:

1) Komitmen efektif (affective comitment)

Komitmen afektif adalah keterikatan emosional, identifikasi serta keterlibatan seorang karyawan pada suatu organisasi. Komitmen afektif seseorang akan menjadi lebih kuat bila pengalamannya dalam suatu organisasi konsisten dengan harapan-harapan dan memuaskan kebutuhan dasarnya dan sebaliknya. Komitmen efektif menunjukkan kuatnya keinginan seseorang untuk terus bekerja bagi suatu organisasi karena ia memang setuju dengan organisasi itu dan memang berkeinginan melakukannya. Karyawan yang mempunyai komitmen efektif yang kuat tetap bekerja dengan organisasi karena mereka menginginkan untuk bekerja pada organisasi itu.

2) Komitmen berkelanjutan (continuance commitment)

Komitmen berkelanjutan merupakan komitmen karyawan yang didasarkan pada pertimbangan apa yang harus dikorbankan bila meninggalkan organisasi dan kerugian yang akan diperoleh karyawan jika tidak melanjutkan pekerjaannya dalam organisasi. Tindakan meninggalkan organisasi menjadi sesuatu yang berisiko tinggi karena karyawan merasa takut akan kehilangan sumbangan yang mereka tanamkan pada tanamkan pada organisasi itu dan menyadari bahwa mereka tak mungkin mencari gantinya. Karyawan yang mempunyai komitmen kontinuan yang tinggi akan berada dalam organisasi karena mereka memang membutuhkan untuk bekerja pada organisasi itu.

3) Komitmen normatif (normative commiment)

Komitmen normatif merupakan komitmen karyawan terhadap organisasinya karena kewajibannya untuk bertahan dalam organisasi untuk alasan-alasan moral atau etis, atau dengan kata lain keyakinan yang memiliki karyawan tentang tanggung jawabnya terhadap organisasi. Tindakan tersebut merupakan hal benar yang harus dilakukan. Komitmen ini berkaitan dengan perasaan karyawan terhadap keharusan untuk tetap bertahan dalam organisasi. Oleh karena itu, karyawan yang memiliki komitmen normatif yang tinggi akan bertahan dalam organisasi karena merasa wajib atau sudah seharusnya untuk loyal kepada organisasi tersebut.

\section{Organizational Citizenship Behavior (OCB)}

Huang (2012) mengemukakan tiga kategori perilaku pekerja, yaitu: (1) berpartisipasi, terikat dan berada dalam suatu organisasi; (2) harus menyelesaikan suatu pekerjaan dan bertindak sesuai dengan prinsip-prinsip yang diatur oleh organisasi; serta(3) melakukan aktivitas yang inovatif dan spontan melebihi persepsi perannya dalam organisasi. Kategori terakhirlah yang sering disebut sebagai organizational citizenship behavior (OCB)

Robbins dan Judge (2008) mendefinisikan OCB sebagai perilaku pilihan yang tidak menjadi bagian dari kewajiban kerja formal seorang karyawan, namun mendukung berfungsinya organisasi tersebut secara efektif. Shweta dan Srirang (2009) menyatakan bahwa OCB ditandai dengan usaha dalam bentuk apapun yang dilakukan berdasarkan kebijaksanaan pegawai yang memberikan manfaat bagi organisasi tanpa mengharapkan imbalan apapun.

Kumar et al (2009) mendifinisikan OCB sebagai perilaku individu yang memberikan kontribusi pada terciptanya efektifitas organisasi dan tidak berkaitan langsung dengan sistem reward organisasi. Kumat et al (2009) menyatakan bahwa OCB merupakan : 
1) Perilaku bebas pekerja yang tidak diharapkan maupun diperlakukan, oleh karena itu organisasi tidak dapat memberikan penghargaan atas munculnya perilaku tersebut ataupun memberikan hukuman atas ketiadaan perilaku tersebut.

2) Perilaku individu yang memberikan manfaat bagi organisasi akan tetapi tidak secara langsung maupun eksplisit diakui dalam sistem penghargaan formal organisasi.

3) Perilaku yang bergantung pada setiap individu untuk memunculkan ataupun menghilangkan perilaku tersebut dalam lingkungan kerja.

4) Perilaku yang berdampak pada terciptanya efektifitas dan efisiensi kerja tim dan organisasi, sehingga memberikan kontribusi bagi produktifitas organisasi secara keseluruhan.

Organ et al (2006) menggambarkan OCB sebagai perilaku individual yang bersifat bebas (discretionary), yang tidak secara langsung dan eksplisit mendapat penghargaan dari sistem imbalan formal, dan yang secara keseluruhan (agregat) meningkatkan efisiensi dan efektifitas fungsi-fungsi organisasi. Bersifat bebas dan sukarela, karena perilaku tersebut tidak diharuskan oleh persyaratan peran atau deskripsi jabatan yang secara jelas dituntut berdasarkan kontrak dengan organisasi, melainkan sebagai pilihan personal, Organ et al (2006) menguraikan definisi tersebut ke dalam beberapa poin sebagai berikut :

1) Perilaku individu yang bebas.

Maksudnya adalah bahwa perilaku tertentu yang dimunculkan dalam konteks tertentu bukan merupakan persyaratan muthak yang tercantum dalam deskripsi pekerjaan yang harus dijalankan oleh seorang individu. Hal ini menyebabkan setiap individu memiliki pilihan secara bebas, apakah akan memunculkan OCB atau tidak, karena seseorang tidak akan dihukum karena tidak mempratekkan perilaku tersebut.

2) Tidak secara langsung dan eksplisit diakui oleh sistem penghargaan formal. Beberapa pekerjaan mencantumkan standar minimal seperti pengalaman, pengetahuan, dan kompetensi untuk memenuhi tanggung jawab pekerjaan secara tertulis. Ketika berbagai tuntutan tersebut dicantumkan dalam diskripsi pekerjaan, atau kontrak kerja, maka perilaku yang timbul dalam rangka memenuhi kewajiban tersebut bukanlah merupakan OCB. Dalam hal ini bukan berarti perilaku yang termasuk OCB tidak akan mendapatkan penghargaan sama sekali. Sebagai contoh ketika seseorang menunjukkan OCB, perilaku yang dimunculkan tersebut dapat merubah pandangan rekan kerja serta atasan dalam mempertimbangkan orang tersebut untuk direkomendasikan agar diberikan kesempatan pekerjaan dengan tanggung jawab lebih besar, diusulkan oleh atasannya untuk dinaikkan gajinya, atau direkomendasikan oleh rekan kerja dan atasannya untuk mendapatkan promosi jabatan. Organ et al. Menyatakan bahwa perbedaan penting yang mendasari pemberian imbalan atau penghargaan yang diberikan tersebut tidak ditetapkan dalam kontrak kerja atau tidak terdapat dalam kebijakan dan prosedur formal organisasi. Pemberian imbalan tersebut bersifat alamiah dan terdapat ketidakpastian dari segi waktu dan cara mendapatkan imbalan tersebut.

3) Secara bersama-sama mendorong fungsi efisiensi dan efektifitas organisasi. Pengertian secara bersama-sama mengandung maksud bahwa OCB muncul pada setiap individu, pada kelompok, hingga pada tingkatan organisasi secara luas. Organ et al, mengungkapkan bahwa beberapa penelitian mengenai OCB secara umum telah dikaitkan dengan indikator efisiensi dan efektivitas pada organisasi seperti efisiensi operasi, kepuasan pelanggan, kinerja keuangan, dan pertumbuhan pendapatan. 
OCB sangat penting artinya untuk menunjang keefektifan fungsi-fungsi organisasi, terutama dalam jangka panjang. Menurut Podsakoff et al (2000), OCB mempengaruhi keefektifan organisasi karena beberapa alasan: (1) OCB dapat membantu meningkatkan produktivitas rekan kerja; (2) OCB dapat membantu meningkatkan produktivitas manajerial; (3) OCB dapat membantu mengefisienkan penggunaan sumber daya organisasi untuk tujuantujuan produktif; (4) OCB dapat menurunkan tingkat kebutuhan akan penyediaan sumber daya organisasi secara umum untuk tujuan-tujuan pemeliharaan karyawan; (5) OCB dapat dijadikan sebagai dasar yang efektif untuk aktivitas-aktivitas koordinasi antar anggotaanggota tim dan antar kelompok-kelompok kerja; (6) OCB dapat meningkatkan kemampuan organisasi untuk mendapatkan dan mempertahankan sumber daya manusia yang handal; (7) OCB dapat meningkatkan stabilitas kinerja organisasi; (8) OCB dapat meningkatkan kemampuan organisasi untuk beradaptasi secara lebih efektif terhadap perubahan-perubahan lingkungannya.

Shweta dan Srirang (2010) menyajikan sebuah tinjauan yang komprehensif berupa kerangka kerja untuk mengemukakan faktor-faktor yang mempengaruhi OCB, diantaranya:

1) Disposisi individu dan motif individu

Disposisi individu seperti positive affectivity, negative affectivity, conscientiousness, agreeableness, dan juga locus of control memainkan peranan penting dalam menentukan tingkat OCB yang ditampilkan oleh pegawai. Selain disposisi individu, pegawai didorong oleh motivasi baik intrinsik atau ekstrinsik untuk menunjukkan OCB.

2) Kohesivitas kelompok

Pegawai pada umumnya berhubungan langsung dengan kelompok kerja dalam pekerjaannya. Hal ini secara jelas memberikan pengaruh pada sikap dan perilaku pegawai tersebut. Kohesivitas kelompok mendorong munculnya OCB yang bertujuan untuk lebih mempererat hubungan agar kelompok menjadi kuat dan efektif.

3) Sikap Pegawai

OCB tergantung pada sikap positif karyawan terhadap pekerjaan mereka serta terhadap organisasi, yang meliputi:

a. Komitmen Organisasi

Dalam beberapa kasus, tingkat komitmen organisasi mempengaruhi timbulnya

OCB. Tingginya tingkat komitmen organisasi tercermin dalam keterlibatan pegawai dalam permasalahan organisasi di luar penugasan secara umum.

b. Kepuasan Kerja

Berbagai studi menunjukkan hubungan yang potitif antara kepuasan kerja dengan OCB

4) Pegawai yang paling mungkin terlibat dalam OCB adalah dalam kondisi manajer menampilkan perilaku kepemimpinan transformasional seperti mempunyai visi, menjadi teladan, menyegarkan intelektual bawahan, dan mengkomunikasikan harapan kinerja yang tinggi. Jelas sekali bahwa perhatian pada munculnya OCB pegawai tergantung pada efektivitas kepemimpinan yang berjalan dalam organisasi.

5) Keadilan Organisasi

Keadilan organisasi mencerminkan sejauh mana pegawai merasa diperlakukan adil oleh organisasi. Organisasi yang mengikuti prinsip-prinsip umum keadilan organisasi akan memastikan bahwa keadilan distributif, keadilan prosedural, dan keadilan interaksional telah memiliki ukuran yang baik dalam organisasi. 
Masing-masing komponen dalam keadilan organisasi memberikan kontribusi yang sangat penting dalam membentuk OCB pegawai dalam organisasi.

\section{Kinerja}

\section{a. Pengertian Kinerja}

Hani Handoko (2002) mengistilahkan kinerja (performance) dengan prestasi kerja yaitu proses melalui mana organisasi mengevaluasi atau menilai prestasi kerja karyawan.

Gibson (2009) mendefinisikan kinerja sebagai hasil dari pekerjaan yang terkait dengan tujuan organisasi seperti kualitas dan kuantitas. Kualitas kerja dinilai dari tanggung jawab dan inisiatif yang dimiliki oleh pegawai dalam menyelesaikan tugasnya sedangkan kuantitas kerja dapat dinilai dari target capaian kerja dan ketepatan waktu dalam penyelesaian pekerjaan.

Hasil kerja seseorang akan memberikan umpan balik bagi orang itu sendiri untuk selalu aktif melakukan pekerjaannya secara baik dan diharapkan akan menghasilkan mutu pekerjaan yang baik pula. Pendidikan mempengaruhi kinerja seseorang karena dapat memberikan wawasan yang lebih luas untuk berinisiatif dan berinovasi dan selanjutnya berpengaruh terhadap kinerjanya.

Sopiah (2008) menyatakan lingkungan juga bisa mempengaruhi kinerja seseorang. Situasi lingkungan yang kondusif, misalnya dukungan dari atasan, teman kerja, sarana dan prasarana yang memadai akan menciptaka kenyamanan tersendiri dan akan memacu kinerja yang baik. Sebaliknya, suasana kerja yang tidak nyaman karena sarana dan prasarana yang tidak memadai, tidak adanya dukungan dari atasan, dan banyak terjadi konflik akan memberi dampak negatif yang mengakibatkan kemerosotan pada kinerja seseorang.

\section{b. Penilaian Kinerja}

Penilaian kinerja (performance appraisal) memainkan peranan yang sangat penting dalam peningkatan motivasi di tempat kerja. Karyawan menginginkan dan memerlukan balikan berkenaan dengan prestasi mereka dan penilaian menyediakan kesempatan untuk memberikan balikan kepada mereka. Jika kinerja tidak sesuai dengan standar, maka penilaian memberikan kesempatan untuk meninjau kemajuan karyawan dan untuk menyusun rencana peningkatan kinerja. Penilaian kinerja merupakan upaya membandingkan prestasi aktual karyawan dengan prestasi kerja dengan yang diharapkan darinya (Dessler 2000).

Dalam penilaian kinerja karyawan tidak hanya menilai hasil fisik, tetapi pelaksanaan pekerjaan secara keseluruhan yang menyangkut berbagai bidang seperti kemampuan kerja, kerajinan, kedisiplinan, hubungan kerja atau hal-hal khusus sesuai dengan bidang dan level pekerjaan yang dijabatnya.

Menurt Dessler (2000) ada lima faktor dalam penilaian kinerja yang populer, yaitu:

1. Prestasi pekerjaan, meliputi: akurasi, ketelitian, keterampilan, dan penerimaan keluaran

2. Kuantitas pekerjaan, meliputi: volume keluaran dan kontribusi

3. Kepemimpinan yang diperlukan, meliputi: membutuhkan saran, arahan atau perbaikan

4. Kedisiplinan, meliputi: kehadiran, sanksi, warkat, regulasi, dapat dipercaya/ diandalkan dan ketepatan waktu

5. Komunikasi, meliputi: hubungan antar karyawan maupun dengan pimpinan, media komunikasi. 
Menurut Hani Handoko (2002) pengukuran kinerja adalah usaha untuk merencanakan dan mengontrol proses pengelolaan pekerjaan sehingga dapat dilaksanakan sesuai tujuan yang telah ditetapkan, penilaian prestasi kerja juga merupakan proses mengevaluasi dan menilai prestasi kerja karyawan diwaktu yang lalu atau untuk memprediksi prestasi kerja di waktu yang akan datang dalam suatu organisasi.

Hani Handoko (2002) menyebutkan bahwa penilaian kinerja terdiri dari 3 kriteria, yaitu :

1. Penilaian berdasarkan hasil yaitu penilaian yang didasarkan adanya target-target dan ukurannya spesifik serta dapat diukur.

2. Penilaian berdasarkan perilaku yaitu penilaian perilaku-perilaku yang berkaitan dengan pekerjaan.

\section{Model Penelitian}

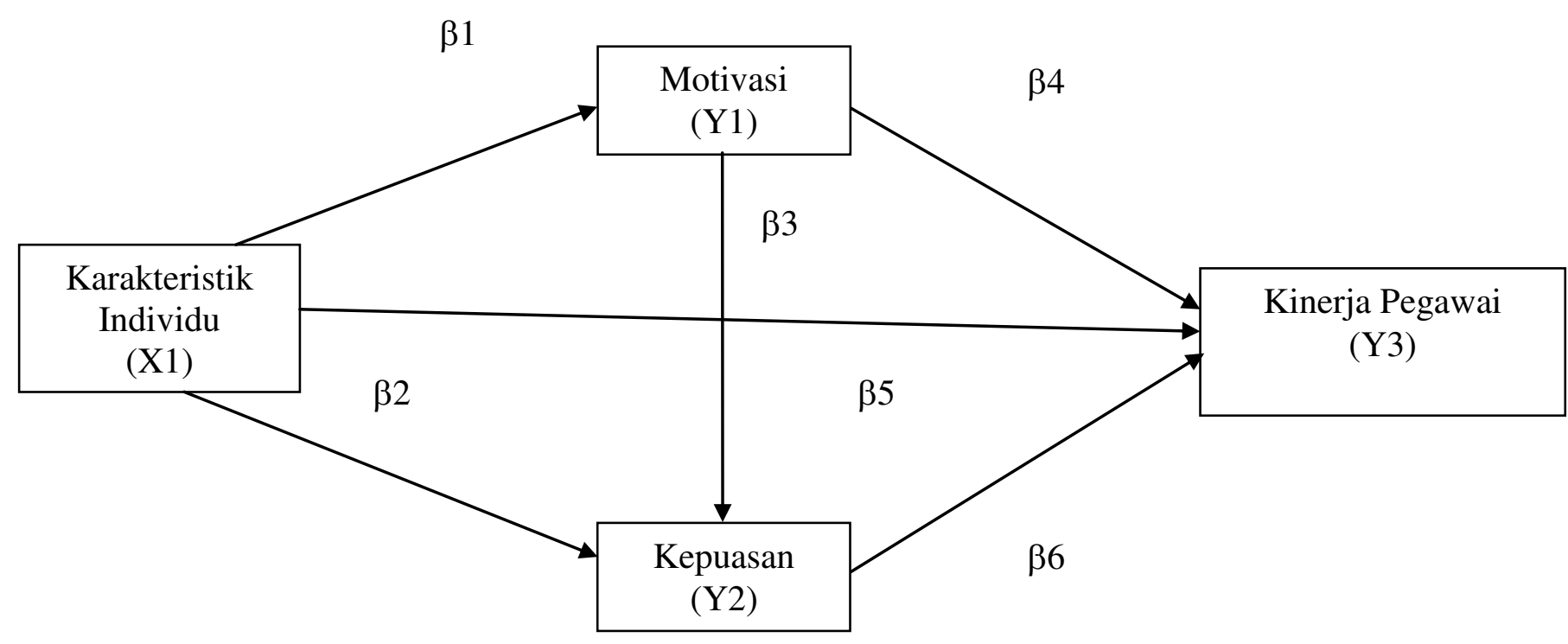

$$
\begin{aligned}
& Y_{1}=a_{1}+b_{1} X_{1}+e_{1} \\
& Y_{2}=a_{2}+b_{2} X_{1}+b_{3} Y_{1}+e_{2} \\
& Y_{3}=a_{3}+b_{4} Y_{1}+b_{5} X_{1}+b_{6} Y_{2}+e_{3}
\end{aligned}
$$

$$
\begin{aligned}
& \text { Keterangan : } \\
& \mathrm{Y}_{3}=\text { Kinerja Pegawai } \\
& \mathrm{X}_{1}=\text { Kepemiminan Transformasional } \\
& \mathrm{Y}_{1}=\text { Komitmen Organisasional } \\
& \mathrm{Y}_{2}=\mathrm{OCB} \\
& \text { a } 1-3=\text { konstanta } \\
& \text { b } 1-5=\text { koefisien regresi } \\
& \mathrm{e}=\text { standar error }
\end{aligned}
$$

\section{Hubungan Antar Variabel}

\section{a. Pengaruh Gaya Kepemimpinan Transformasional terhadap Komitmen Organisasi}

Kepemimpinan Transformasional menyangkut nilai-nilai yang relevan bagi proses pertukaran seperti: kejujuran, keadilan, tanggung jawab dan pertukaran imbalan (Burns, 1978). Untuk menghubungkan pemimpin dengan bawahannya diperlukan gaya 
kepemimpinan sehingga akan membentuk suatu hubungan bawahan dengan organisasi dan mempunyai implikasi dalam keputusan bawahan untuk meneruskan atau tidak meneruskan hubungannya dalam organisasi. Komitmen organisasi sebagai kekuatan dari identifikasi intividu dan keterlibatan dalam organisasi khusus, meliputi kepercayaan, dukungan terhadap tujuan dan nilai-nilai organisasi, kemauan untuk menggunakan upaya yang sungguh-sungguh untuk kepentingan organisasi, dan keinginan yang kuat untuk memelihara keanggotaan dalam organisasi.

Hasil penelitian Kaihatu dan Rini (2007) menyatakan bahwa kepemimpinan transformasional berpengaruh signifikan terhadap komitmen organisasi.

Berdasarkan uraian diatas maka peneliti merumuskan hipotesis 1 sebagai berikut:

Hipotesis 1: Gaya Kepemimpinan transformasional berpengaruh positif terhadap komitmen organisasional pada Dinas Pertanian dan Kehutanan Kabupaten Rembang

\section{b. Pengaruh Gaya Kepemimpinan Transformasional terhadap OCB}

Dalam konteks perilaku keorganisasian, perilaku ekstra peran atau perilaku baik warga organisasi yang populer dikenal sebagai organizational citizenship behavior (OCB) amat penting dimiliki karena turut memberikan kontribusi positif terhadap kualitas kehidupan kerja dan kinerja organisasi pada saat organisasi diharapkan pada berbagai situasi yang kurang kondusif dan kualitas kehidupan kerja menurun maka perilaku (OCB) perlu didukung. Bentuk dapat diimplementasikan dalam perilaku yaitu : Altruism (perilaku membantu dengan segera terhadap orang lain), Conscientiousness, (sikap berhati-hati/mendengarkan kata hati), Sportmanship (sikap sportif seperti toleransi terhadap dihindari tanpa adanya komplain), Courtesy (kesopanan seperti memberitahu yang lain dalam mencegah kejadian dalam kerja yang menimbulkan suatu masalah), Civic virtue, (berpartisipasi dan memperhatikan kelangsungan hidup perusahaan).

Seorang pemimpin dalam lingkungan organisasi diharapkan dapat menunjukkan kewibawaan dan menimbulkan rasa hormat bagi pengikutnya sehingga membuat para pengikut merasa terinspirasi untuk mengikuti dan menunjukkan perilaku ekstra peran sebagai warga yang baik untuk mengikuti dan menunjukkan perilaku ekstra peran sebagai warga yang baik bagi organisasinya. Keefektifan kepemimpinan akan mendorong meningkatnya perilaku ekstra pengikutnya.

Hasil penelitian Lamidi (2008) menyatakan bahwa Kepemimpinan transformasional berpengaruh signifikan terhadap Organization Citizenship Behavior (OCB) para dosen di Unisri Surakarta. Semakin tinggi persepsi dosen terhadap kepemimpinan transformasional, maka para dosen akan menunjukkan perilakuekstra peran (OCB) yang semakin tinggi.

Berdasarkan uraian diatas maka peneliti merumuskan Hipotesis 2 sebagai berikut:

Hipotesis 2: Gaaya kepemimpinan transformasional berpengaruh positif terhadap OCB pada Dinas Pertanian dan Kehutanan Kabupaten Rembang

\section{c. Pengaruh Komitmen Organisasional terhadap OCB}

Organizational Citizenship Behavior (OCB) dapat timbul dari berbagai faktor dalam organisasi, di antaranya karena adanya kepuasan kerja dari karyawan dan komitmen organisaasi yang tinggi (Robbin \& Judge, 2007). Ketika karyawan merasakan kepuasan terhadap pekerjaan yang dilakukannya, maka karyawan tersebut akan bekerja secara maksimal dalam menyelesaikan pekerjaannya, bahkan melakukan beberapa hal yang mungkin di luar tugasnya. Begitu juga dengan ketika seseorang mempunyai komitmen yang tinggi terhadap organisasinya, maka orang tersebut akan melakukan apapun untuk memajukan perusahaannya karena keyakinannya terhadap organisasinya (Luthans, 1995). 
Ketika seseorang mendapatkan kepuasan kerja dan mempunyai komitmen yang tinggi terhadap organisasi, karyawan akan memberikan pelayanan yang baik dan begitu juga sebaliknya, ketika karyawan saja tidak mengalami kepuasan maka pelayanan yang diberikan kepada konsumen, dalam hal ini para pegawai bisa tidak memuaskan. Kepuasan kerja diartikan sebagai tanggapan emosional seseorang terhadap aspek-aspek di dalam atau pada keseluruhan pekerjaannya (Nawawi, 1998). Keadaan emosional atau sikap seseorang tersebut akan diperlihatkan dalam bentuk tanggung jawab, perhatian, serta perkembangan kinerjanya.

Berdasarkan uraian diatas maka peneliti merumuskan Hipotesis 3 sebagai berikut:

Hipotesis 3: Komitmen organisasional berpengaruh positif terhadap OCB pada Dinas Pertanian dan Kehutanan Kabupaten Rembang.

\section{d. Pengaruh Komitmen Organisasional terhadap Kinerja}

Komitmen Organisasional kadang-kadang disebut komitmen kerja, mencerminkan identifikasi dan ikatan seorang individu pada organisasi. Seseorang yang sangat berkomitmen mungkin akan melihat dirinya sebagai anggota sejati dari sebuah perusahaan, mengabaikan sumber ketidakpuasan kecil, dan melihat dirinya tetap sebagai anggota organisasi. Sebaliknya, seseorang yang kurang berkomitmen lebih berkemungkinan melihat dirinya sendiri sebagai orang luar.

Organisasi dapat melakukan beberapa hal definitif untuk meningkatkan kepuasan dan komitmen, tetapi tersedia beberapa panduan spesifik. Untuk satu hal, jika organisasi memperlakukan karyawannya dengan adil dan memberikan penghargaan yang masuk akal serta keamanan kerja, karyawannya lebih berkemungkinan untuk merasa puas dan berkomitmen.

Hasil penelitian Fakhrizal, Yunus dan Amri (2012) menyatakan bahwa komitmen organisasi baik secara parsial maupun simultan berpengaruh terhadap kinerja pegawai Dinas Pengelolaan Keuangan dan Kekayaan Aceh.

Berdasarkan uraian diatas maka peneliti merumuskan Hipotesis 4 sebagai berikut:

Hipotesis 4: komitmen organisasional berpengaruh positif terhadap kinerja pegawai Dinas Pertanian dan Kehutanan Kabupaten Rembang

\section{e. Pengaruh Gaya Kepemimpinan Tranformasional terhadap Kinerja}

Keberhasilan suatu organisasi baik sebagai keseluruhan maupun berbagai kelompok dalam suatu organisasi tertentu, sangat tergantung pada mutu kepemimpinan yang terdapat dalam organisasi yang bersangkutan. Bahkan kiranya dapat dikatakan bahwa mutu kepemimpinan yang terdapat dalam suatu organisasi memainkan peranan yang sangat dominan dalam keberhasilan organisasi tersebut dalam menyelenggarakan berbagai kegiatannya terutama terlihat dalam kinerja para pegawainya (Siagian, 1999)

Gaya kepemimpinan seorang pemimpin akan sangat mempengaruhi kondisi kerja, dimana akan berhubungan dengan bagaimana karyawan menerima suatu gaya kepemimpinan, senang atau tidak, suka atau tidak. Di satu sisi gaya kepemimpinan tertentu dan menyebabkan peningkatan kinerja disisi lain dapat menyebabkan penurunan kinerja.

Hasil penelitian Marjam (2010) menyatakan bahwa Kepemimpinan transformasional berpengaruh signifikan terhadap Kinerja pegawai. Penerapan kepemimpinan transformasional yang semakin efektif, ditunjukkan dari kepuasan kerja dan kepercayaan bawahan yang semakin tinggi, loyalitas dan rasa hormat kepada atasan, serta semakin tingginya motivasi bawahan untuk meningkatkan prestasi kerja.

Berdasarkan uraian diatas maka peneliti merumuskan Hipotesis 5 sebagai berikut: 
Hipotesis 5: Gaya kepemimpinan transformasional berpengaruh positif terhadap kinerja pegawai Dinas Pertanian dan Kehutanan Kabupaten Rembang

\section{f. Organizational Citizenship Behavior (OCB) terhadap Kinerja}

Organizational Citizenship Behavior (OCB) merupakan suatu perilaku sukarela yang tampak dan dapat diamati. OCB merupakan suatu perilaku. Oleh karena itu, sebenarnya OCB didasari oleh suatu motif/nilai yang dominan. Kesukarelaan dalam bentuk perilaku bentuk tentu mencerminkan kerelaan yang sebenarnya. Memang untuk mengetahui nilainilai diri karyawan tidak selalu mudah. Oleh karena itu, secara pragmatis praktek manajemen dalam organisasi sering berorientasi pada apa yang dapat diamati yaitu perilaku. Pembentukan perilaku pun sering didasarkan pada reward dan punishment yang bersifat eksternal.

OCB memiliki lingkup yang luas dibandingkan dengan komitmen karyawan secara pribadi karena arti dari citizen itu sendiri adalah kewarganegaraan sehingga memiliki tanggung jawab dan rasa cinta terhadap pekerjaan secara sukarela dan tanpa diawali. Perilaku OCB tidak terdapat pada job description karyawan, tetapi sangat diharapkan, karena mendukung peningkatan efektivitas dan kelangsungan hidup organisasi, khususnya dalam lingkungan bisnis yang persaingannya semakin tajam. Karyawan yang memiliki OCB akan memiliki loyalitas yang tinggi terhadap organisasi tempatnya bekerja, dan dengan sendirinya akan merasa nyaman dan aman terhadap pekerjaannya.

Hasil pembahasan Marita menyatakan bahwa OCB mempunyai pengaruh yang signifikan pada kinerja organisasi dan keberhasilan organisasi mencapai tujuannya. Sehingga seharusnya organisasi memberikan perhatian lebih pada OCB anggotanya untuk lebih mendukung kelancaran organisasi mencapai tujuannya.

Berdasarkan uraian diatas maka peneliti merumuskan Hipotesis 6 sebagai berikut:

Hipotesis 6: OCB berpengaruh positif terhadap kinerja pegawai Dinas Pertanian dan Kehutanan Kabupaten Rembang

\section{Metode Penelitian}

\section{Populasi dan Sampel}

Populasi adalah keseluruhan subyek penelitian (Arikunto, 2002). Berdasarkan pengertian tersebut dapat dijelaskan populasi merupakan keseluruhan obyek yang diteliti, dapat berupa manusia, gejala-gejala atau peristiwa-peristiwa yang mempunyai karakteristik tertentu serta merupakan sumber data dan menentukan keberhasilan penelitian.Dalam penelitian ini, yang menjadi populasi adalah seluruh pegawai di Dinas Pertanian dan Kehutanan Kabupaten Rembang sebanyak 103 orang pegawai.

Sampel merupakan bagian terkecil dari suatu populasi. Dengan mempertimbangkan bahwa elemen populasi relatif sedikit dan variabilitas setiap elemen relatif tinggi (heterogen), maka pengambilan sampel untuk dijadikan responden dalam penelitian ini adalah menggunakan metode sensus, dimana setiap anggota populasi secara keseluruhan dijadikan sebagai sampel. Jumlah responden yang diambil sebagai sampel adalah sebanyak 103 pegawai di Dinas Pertanian dan Kehutanan Kabupaten Rembang.

\section{Definisi Konsep dan Operasional}

Kepemimpinan transformasional yang mencakup perubahan organisasi yang memprediksi hubungan emosional pengikut pada pimpinannya dan stimulasi emosional dan 
motivasional pengikut sebagai konsekuensi dari perilaku pimpinan (House, Woycke, dan Fodor, 1988 dalam Hartog dan Van Muijen, 1997. Kepemimpinan transformasional memiliki dimensi yaitu : kharisma, Motivasi Inspirasional, Stimulasi Intelektual, Perhatian Individual.

Komitmen organisasional adalah suatu kondisi yang dirasakan oleh pegawai yang dapat menimbulkan perilaku yang positif yang kuat terdapat organisasi kerja yang dimiliki dalam bentuk affective commitment, continueance commitment, normative commitmen (Allen dan Meyer, 1993). Variabel Komitmen organisasional terdiri dari tiga dimensi yaitu affective commitment (Komitmen Efektif), continueance commitment (Komitmen Continueance), normative commitmen (Komitmen Normatif)

Menurut Organ (1988) dalam Bolino, Turnley dan Bloodgood (2002), OCB adalah Perilaku karyawan yang melebihi peran yang diwajibkan yang tidak secara langsung atau eksplisit diakui oleh sistem reward.. Variabel OCB terdiri dari lima dimensi yaitu Alturism, Civic Virtue, Conscientiousness, Sportsmanship, Courtesy.

Gibson (1997) mendefinisikan kinerja sebagai hasil dari pekerjaan yang terkait dengan tujuan organisasi seperti kualitas dan kuantitas Variabel Kinerja terdiri dari tiga dimensi yaitu pengetahuan kemampuan dan ketrampilan kerja, kualitas hasil kerja dan efisiensi kerja.

\section{Hasil Analisis dan Pembahasan}

Pengambilan data dalam penelitian ini dilaksanakan pada tanggal 7 April 2014 sampai dengan 17 April 2014, Pengambilan sampel menggunakan metode sensus dengan membagikan 103 kuesioner, diisi dengan benar oleh responden sesuai dengan petunjuk pengisian.

\section{Deskripsi Responden}

Gambaran identitas responden akan memberikan deskripsi mengenai keadaan responden. Sesuai dengan data kuesioner, responden diidentifikasikan menurut jenis kelamin, umur, masa kerja, dan pendidikan terakhir, dengan rincian sebagai berikut:

Tabel 1

Deskripsi Responden Berdasarkan Jenis Kelamin, Usia, Pendidikan Terakhir dan Masa Kerja

\begin{tabular}{|c|c|c|c|}
\hline & & Frekuensi & Prosentase (\%) \\
\hline Jenis Kelamin & Pria & 79 & 76,70 \\
\hline & Wanita & 24 & 23,30 \\
\hline Usia & $<30$ Tahun & 3 & 2,91 \\
\hline & 30-40 Tahun & 33 & 32,04 \\
\hline & $>40$ Tahun & 67 & 65,05 \\
\hline Pendidikan Terakhir & SLTA & 46 & 44,66 \\
\hline & Diploma & 4 & 3,89 \\
\hline & Sarjana (S1) & 48 & 46,60 \\
\hline & Pasca Sarjana (S2) & 5 & 4,85 \\
\hline Masa Kerja & 1-5 Tahun & 13 & 12,60 \\
\hline & 5-10 Tahun & 23 & 22,30 \\
\hline & 11-15 Tahun & 22 & 21,40 \\
\hline & $>15$ Tahun & 45 & 43,70 \\
\hline
\end{tabular}

Sumber: Data primer yang diolah, 2014 
Dari Tabel 1 diatas dapat diketahui bahwa responden pria sejumlah 79 orang atau sebesar 76,7 \% sedangkan responden wanita sejumlah 24 orang atau sebesar 23,3\%. Sehingga dapat disimpulkan bahwa responden dalam penelitian ini didominasi oleh responden pria.

Untuk jumlah responden dengan umur kurang dari 30 tahun sebesar 2,9\% yaitu ada 3 orang, umur 30-40 tahun sebesar 32\% yaitu ada 33 orang dan umur diatas 40 tahun sebesar $65 \%$ yaitu ada 67 orang. Sehingga dapat disimpulkan bahwa berdasarkan umur responden penelitian ini didominasi oleh umur lebih dari 40 tahun. Sedangkan untuk responden dengan jumlah terkecil adalah pegawai dengan umur dibawah 30 tahun.

Selain itu juga diketahui bahwa jumlah responden dengan tingkat pendidikan SLTA sebesar 44,7\% yaitu sejumlah 46 orang. Untuk latar belakang pendidikan Diploma sebesar $4 \%$ yaitu sejumlah 4 responden, pegawai dengan latar pendidikan Sarjana atau Strata 1 sebesar $46,6 \%$ atau sejumlah 48 orang. Dan untuk pegawai dengan latar belakang pendidikan Pasca Sarjana atau S2 sebesar 4,9\% atau sejumlah 5 orang. Sehingga dapat disimpulkan bahwa berdasarkan latar belakang pendidikan responden penelitian yang merupakan pegawai Dinas Pertanian dan Kehutanan Kabupaten Rembang didominasi oleh lulusan Sarjana S1. Dari tabel diatas juga menunjukkan bahwa jumlah responden terbesar berdasarkan masa kerja adalah selama 1-5 tahun sejumlah 13 orang atau sebesar 12,6\%, masa kerja 5-10 tahun sejumlah 23 orang atau sebesar 22,3\%, masa kerja 10-15 tahun sejumlah 22 orang atau 21,4 $\%$ dan masa kerja lebih dari 15 tahun ada 45 orang atau 43,7\%. Untuk responden dengan jumlah masa terkecil adalah pegawai dengan masa kerja 1-5 tahun 12,6\% sejumlah 13 orang, lebih dari 15 tahun $43,7 \%$ sejumlah 45 orang masa kerja paling banyak

\section{Deskripsi Variabel}

Tabel 2

Deskripsi Variabel Gaya Kepemimpinan Transformasional (X1)

\begin{tabular}{|l|r|r|r|r|r|r|r|r|r|r|r|r|}
\hline & $\mathrm{X} 1.1$ & $\mathrm{X} 1.2$ & $\mathrm{X} 1.3$ & $\mathrm{X} 1.4$ & $\mathrm{X} 1.5$ & $\mathrm{X} 1.6$ & $\mathrm{X} 1.7$ & $\mathrm{X} 1.8$ & $\mathrm{X} 1.9$ & $\mathrm{X} 1.10$ & $\mathrm{X} 1.11$ & $\mathrm{X} 1.12$ \\
\hline Mean & 5.82 & 5.03 & 6.10 & 5.94 & 5.69 & 5.70 & 5.43 & 6.12 & 6.07 & 5.57 & 5.83 & 5.88 \\
\hline Med & 6.00 & 5.00 & 6.00 & 6.00 & 6.00 & 6.00 & 5.00 & 6.00 & 6.00 & 6.00 & 6.00 & 6.00 \\
\hline Mod & 6 & 5 & 6 & 6 & 6 & 6 & 5 & 6 & 6 & 6 & 6 & 6 \\
\hline Min & 2 & 2 & 3 & 4 & 1 & 3 & 4 & 5 & 4 & 1 & 4 & 5 \\
\hline Max & 7 & 7 & 7 & 7 & 7 & 7 & 7 & 7 & 7 & 7 & 7 & 7 \\
\hline
\end{tabular}

Sumber: Data primer yang diolah, 2014

Dari tabel diatas dapat diketahui bahwa jawaban yang paling banyak diisikan dalam kuesioner penelitian ini mengenai item-item dalam variabel Gaya Kepemimpinan Transformasional (X1) adalah nilai dengan bobot 6 yaitu Setuju.

Tabel 3

Deskripsi Variabel Komitmen Organisasional (Y1)

\begin{tabular}{|l|r|r|r|r|r|r|r|r|r|r|r|r|}
\hline & Y1.1 & Y1.2 & Y1.3 & Y1.4 & Y1.5 & Y1.6 & Y1.7 & Y1.8 & Y1.9 & Y1.10 & Y1.11 & Y1.12 \\
\hline Mean & 5.37 & 5.89 & 5.83 & 5.46 & 6.16 & 5.10 & 5.18 & 5.84 & 5.13 & 5.08 & 4.16 & 4.64 \\
\hline Med & 6.00 & 6.00 & 6.00 & 6.00 & 6.00 & 5.00 & 5.00 & 6.00 & 5.00 & 5.00 & 4.00 & 5.00 \\
\hline Mod & 6 & 6 & 6 & 6 & 6 & 6 & 5 & 6 & 6 & 5 & 4 & 4 \\
\hline Min & 2 & 1 & 1 & 2 & 4 & 2 & 3 & 4 & 1 & 2 & 1 & 1 \\
\hline Max & 7 & 7 & 7 & 7 & 7 & 7 & 7 & 7 & 7 & 7 & 6 & 7 \\
\hline
\end{tabular}


Prima Kartika Sari

Euis Soliha
Jurnal Manajemen Bisnis Indonesia

Vol. 3, Nomor 3, Juni 2016

\begin{tabular}{|l|r|r|r|r|r|r|r|r|r|r|r|r|}
\hline & $\mathrm{Y} 1.13$ & $\mathrm{Y} 1.14$ & $\mathrm{Y} 1.15$ & $\mathrm{Y} 1.16$ & $\mathrm{Y} 1.17$ & $\mathrm{Y} 1.18$ & $\mathrm{Y} 1.19$ & $\mathrm{Y} 1.20$ & $\mathrm{Y} 1.21$ & $\mathrm{Y} 1.22$ & $\mathrm{Y} 1.23$ & $\mathrm{Y} 1.24$ \\
\hline Mean & 5.86 & 4.94 & 4.70 & 5.83 & 4.92 & 5.99 & 4.48 & 5.94 & 4.96 & 5.87 & 6.03 & 6.00 \\
\hline Med & 6.00 & 5.00 & 5.00 & 6.00 & 5.00 & 6.00 & 4.00 & 6.00 & 5.00 & 6.00 & 6.00 & 6.00 \\
\hline Mod & 6 & 6 & 5 & 6 & 5 & 6 & 4 & 6 & 4 & 6 & 6 & 6 \\
\hline Min & 2 & 2 & 2 & 1 & 1 & 2 & 1 & 1 & 2 & 4 & 4 & 4 \\
\hline Max & 7 & 7 & 6 & 7 & 6 & 7 & 6 & 7 & 7 & 7 & 7 & 7 \\
\hline
\end{tabular}

Sumber: Data primer yang diolah, 2014

Dari tabel diatas dapat diketahui bahwa jawaban yang paling banyak diisikan dalam kuesioner penelitian ini mengenai item-item dalam variabel Komitmen Organisasional (Y1) adalah nilai dengan bobot 6 yaitu Setuju.

Tabel 4

Deskripsi Variabel OCB (Y2)

\begin{tabular}{|l|r|r|r|r|r|r|r|r|r|}
\hline & \multicolumn{1}{|c|}{ Y2.1 } & Y2.2 & \multicolumn{1}{|c|}{ Y2.3 } & \multicolumn{1}{|c|}{ Y2.4 } & Y2.5 & Y2.6 & Y2.7 & Y2.8 & Y2.9 \\
\hline Mean & 5.82 & 5.73 & 5.87 & 5.75 & 5.33 & 5.72 & 5.79 & 5.83 & 6.18 \\
\hline Med & 6.00 & 6.00 & 6.00 & 6.00 & 5.00 & 6.00 & 6.00 & 6.00 & 6.00 \\
\hline Mod & 6 & 6 & 6 & 6 & 5 & 6 & 6 & 6 & 6 \\
\hline Min & 4 & 4 & 4 & 5 & 4 & 4 & 2 & 4 & 5 \\
\hline Max & 7 & 7 & 7 & 7 & 7 & 7 & 7 & 7 & 7 \\
\hline
\end{tabular}

\begin{tabular}{|l|r|r|r|r|r|r|r|r|r|}
\hline & Y2.10 & Y2.11 & Y2.12 & Y2.13 & Y2.14 & Y2.15 & Y2.16 & Y2.17 & Y2.18 \\
\hline Mean & 5.92 & 5.74 & 6.10 & 6.36 & 5.98 & 5.19 & 6.15 & 5.83 & 6.14 \\
\hline Med & 6.00 & 6.00 & 6.00 & 6.00 & 6.00 & 5.00 & 6.00 & 6.00 & 6.00 \\
\hline Mod & 6 & 6 & 6 & 6 & 6 & 5 & 6 & 6 & 6 \\
\hline Min & 4 & 4 & 4 & 5 & 2 & 2 & 4 & 4 & 4 \\
\hline Max & 7 & 7 & 7 & 7 & 7 & 6 & 7 & 7 & 7 \\
\hline
\end{tabular}

Sumber: Data primer yang diolah, 2014.

Dari tabel diatas dapat diketahui bahwa jawaban yang paling banyak diisikan dalam kuesioner penelitian ini mengenai item-item dalam variabel OCB (Y2) adalah nilai dengan bobot 6 yaitu Setuju.

Tabel 5

Deskripsi Variabel Kinerja (Y3)

\begin{tabular}{|l|r|r|r|r|r|r|r|r|r|r|r|}
\hline & Y3.1 & Y3.2 & Y3.3 & Y3.4 & Y3.5 & Y3.6 & Y3.7 & Y3.8 & Y3.9 & Y3.10 & Y3.11 \\
\hline Mean & 6.06 & 5.61 & 6.10 & 5.55 & 5.83 & 5.83 & 6.02 & 5.69 & 5.90 & 6.13 & 6.15 \\
\hline Med & 6.00 & 6.00 & 6.00 & 6.00 & 6.00 & 6.00 & 6.00 & 6.00 & 6.00 & 6.00 & 6.00 \\
\hline Mod & 6 & 6 & 6 & 6 & 6 & 6 & 6 & 6 & 6 & 6 & 6 \\
\hline Min & 5 & 4 & 4 & 2 & 3 & 4 & 4 & 4 & 4 & 3 & 5 \\
\hline Max & 7 & 7 & 7 & 7 & 7 & 7 & 7 & 7 & 7 & 7 & 7 \\
\hline
\end{tabular}

Sumber: Data primer yang diolah, 2014. 
Dari tabel diatas dapat diketahui bahwa jawaban yang paling banyak diisikan dalam kuesioner penelitian ini mengenai item-item dalam variabel Kinerja Pegawai (Y3) adalah nilai dengan bobot 6 yaitu Setuju.

\section{Uji Validitas}

Uji validitas digunakan untuk menunjukkan seberapa jauh ketepatan dan kecermatan suatu alat ukur dalam melakukan fungsinya. Dalam pengujian validitas dibantu dengan program SPSS untuk menentukan apakah kuesioner tersebut sudah valid atau belum.

Pengujian validitas menggunakan metode analisis faktor. Untuk mengetahui valid tidaknya suatu variabel yang diuji, dilakukan dengan membandingkan nilai component matriks atau faktor loading-nya dengan 0,4. Jika hasilnya lebih besar dari 0,4 berarti valid dan jika lebih kecil maka item dari variabel yang diuji di drop dulu kemudian diuji kembali. Sedangkan untuk mengetahui kecukupan sampel, ditentukan dengan nilai KMO (KaiserMeyer-Olkin) and Bartlett's Test lebih besar dari 0,5. Adapun hasil uji validitas dari masingmasing variabel dalam penelitian ini adalah sebagai berikut:

Nilai KMO dan Bartlett's Test variabel gaya kepemimpinan transformasional adalah 0,604 sehingga kecukupan sampel pada variabel kepemimpinan tranformasional telah memenuhi persyaratan yaitu diatas 0,5. Dan diketahui bahwa nilai Component Matrix atau Loading Factor dari 12 indikator gaya kepemimpinan transformasional (X2) 8 indikator valid karena telah memenuhi persyaratan yaitu diatas 0,4 .

Nilai KMO dan Bartlett's Test variabel komitmen organisasional adalah 0,721 sehingga kecukupan sampel pada variabel komitmen organisasional telah memenuhi persyaratan yaitu diatas 0,5. Sedangkan untuk nilai Component Matrix atau Loading Factor dari 24 indikator komitmen organisasional (Y1) 15 indikator valid karena telah memenuhi persyaratan yaitu diatas 0,4 .

Variabel OCB memiliki nilai KMO dan Bartlett's Test adalah 0,618 sehingga kecukupan sampel pada variabel OCB telah memenuhi persyaratan yaitu diatas 0,5. Selanjutnya diketahui bahwa nilai Component Matrix atau Loading Factor dari 18 indikator OCB (Y2) 11 indikator valid karena telah memenuhi persyaratan yaitu diatas 0,4.

Nilai KMO dan Bartlett's Test variabel Kinerja setelah dilakukan analisi ulang dikarenakan terdapat beberapa indikator yang memiliki loading factor yang tidak valid adalah sebesar 0,762 sehingga kecukupan sampel pada variabel kinerja telah memenuhi persyaratan yaitu diatas 0,5. Untuk nilai komponen matrix atau Loading Factor dari 11 indikator yang terukur secara keseluruhan diperoleh nilai lebih dari 0,4 dan 10 indikator yang valid.

\section{Uji Reliabilitas}

Variabel atau konstruk dikatakan reliabel atau handal jika jawaban seseorang terhadap pernyataan adalah konsisten atau stabil dari waktu ke waktu. Suatu konstruk atau variabel dikatakan reliabel jika memberikan nilai Cronbach Alpha lebih besar dari 0,7. Adapun hasil uji reliabilitas dari masing-masing variabel dalam penelitian ini dapat dilihat pada hasil perhitungan dari SPSS sebagai berikut: 
Tabel 6

Hasil Uji Reliabilitas

\begin{tabular}{|c|l|c|c|c|}
\hline Variabel & \multicolumn{1}{|c|}{ Nama Variabel } & Cronbach's alpha & Nilai & Keterangan \\
\hline X1 & $\begin{array}{l}\text { Gaya Kepemimpinan } \\
\text { Transformasional }\end{array}$ & 0,799 & 0,7 & Reliabel \\
\hline Y1 & $\begin{array}{l}\text { Komitmen } \\
\text { Organisasional }\end{array}$ & 0,821 & 0,7 & Reliabel \\
\hline Y2 & OCB & 0,782 & 0,7 & Reliabel \\
\hline Y3 & Kinerja & 0,831 & 0,7 & Reliabel \\
\hline
\end{tabular}

Sumber: Data primer yang diolah, 2014

Dari Tabel 6 diatas dapat diketahui bahwa terdapat nilai Cronbach alpha dari variabel Gaya Kepemimpinan Transformasional adalah sebesar 0,799 atau lebih besar dari 0,7. Sehingga dapat disimpulkan bahwa konsistensi alat ukurnya baik atau reliabel. Untuk variabel Komitmen Organisasional adalah sebesar 0,821 atau lebih besar dari 0,7. Sehingga dapat disimpulkan bahwa konsistensi alat ukurnya baik atau reliabel. Nilai Cronbach alpha dari variabel OCB adalah sebesar 0,782 atau lebih besar dari 0,7. Sehingga dapat disimpulkan bahwa konsistensi alat ukurnya baik atau reliabel.

Sedangkan untuk variabel Kinerja atau Y3 memiliki nilai Cronbach alpha dari sebesar 0,831 atau lebih besar dari 0,7. Sehingga dapat disimpulkan bahwa konsistensi alat ukurnya baik atau reliabel.

\section{Analisis Regresi}

Analisis regresi digunakan untuk menunjukkan ada tidaknya pengaruh variabel bebas terhadap variabel terikat. Dalam penelitian ini variabel bebasnya adalah Gaya Kepemimpinan Transformasional (X1) sedangkan variabel terikatnya adalah Komitmen Organisasional (Y1), OCB (Y2) dan Kinerja (Y3). Adapun hasil analisis regresi yang diperoleh adalah sebagai berikut:

Tabel 7

Koefisien Regresi Gaya Kepemimpinan Transformasional Terhadap Komitmen Organisasional

\begin{tabular}{|c|c|c|c|c|c|c|}
\hline Variabel & $\begin{array}{c}\text { Adj } \\
\text { R-Square }\end{array}$ & Hasil Uji F & Sig & $\begin{array}{c}\text { Koefisien } \\
\text { Beta }\end{array}$ & $\begin{array}{c}\text { Hasil } \\
\text { t-Hitung }\end{array}$ & Sig \\
\hline $\begin{array}{c}\text { Gaya } \\
\text { Kepemimpinan } \\
\text { Transformasional }\end{array}$ & 0,516 & 107,768 & 0,00 & 0,718 & 10,381 & 0,000 \\
\hline
\end{tabular}

Variabel Dependen: Komitmen Organisasional

Sumber: Data primer yang diolah, 2014

Adapun hasil uji Adjusted $R$ Square $\left(\mathrm{R}^{2}\right)$ dari variabel Gaya Kepemimpinan Transformasional terhadap variabel Komitmen Organisasional adalah sebesar 0,516. Hal ini menunjukkan bahwa variabel Gaya Kepemimpinan Transformasional memberikan kontribusi sebesar 51,6\% terhadap variabel Komitmen Organisasional. Dan berdasarkan Uji F diperoleh nilai $F$ hitung sebesar 107,768 dengan signifikansi 0,00. Dari nilai tersebut dapat disimpulkan bahwa variabel Gaya Kepemimpinan Transformasional memberikan pengaruh yang positif dan signifikan terhadap Komitmen Organisasional dikarenakan nilai Signifikansi kurang dari 0,05 . 
Persamaan regresi yang dapat dibentuk dari tabel 8 diatas adalah:

$$
\mathrm{Y} 1=0,718 \mathrm{X} 1
$$

Melalui persamaan regresi tersebut dapat disimpulkan hal-hal sebagai serikut:

- Variabel Gaya Kepemimpinan Transformasional memberikan pengaruh yang positif dan signifikan terhadap Komitmen Organisasional dengan koefisien Beta sebesar 0,718 atau $\beta 1$.

\section{Tabel 8}

Koefisien Regresi Gaya Kepemimpinan Transformasional, Komitmen Organisasional terhadap OCB

\begin{tabular}{|c|c|c|c|c|c|c|}
\hline Variabel & $\begin{array}{c}\text { Adj } \\
\text { R-Square }\end{array}$ & Hasil Uji F & Sig & $\begin{array}{c}\text { Koefisien } \\
\text { Beta }\end{array}$ & $\begin{array}{c}\text { Hasil } \\
\text { t-Hitung }\end{array}$ & Sig \\
\hline $\begin{array}{c}\text { Gaya } \\
\text { Kepemimpinan } \\
\text { Transformasional }\end{array}$ & 0,193 & 11,968 & 0,00 & 0,276 & 2,138 & 0,035 \\
\cline { 1 - 4 } $\begin{array}{c}\text { Komitmen } \\
\text { Organisasional }\end{array}$ & & & & 0,197 & 1,524 & 0,131 \\
\cline { 1 - 5 }
\end{tabular}

Variabel Dependen: OCB

Sumber: Data primer yang diolah, 2014.

Hasil uji Adjusted $R$ Square $\left(\mathrm{R}^{2}\right)$ dari variabel Gaya Kepemimpinan Transformasional dan Komitmen Organisasional terhadap variabel OCB adalah sebesar 0,193. Hal ini menunjukkan bahwa variabel Gaya Kepemimpinan Transformasional dan Komitmen Organisasional secara bersama-sama memberikan kontribusi sebesar 19,3\% terhadap variabel OCB. Dan berdasarkan Uji F diperoleh nilai $F$ hitung sebesar 11,968 dengan signifikansi 0,00. Dari nilai tersebut dapat disimpulkan bahwa variabel Gaya Kepemimpinan Transformasional dan Komitmen Organisasional secara bersama-sama memberikan pengaruh yang positif dan signifikan terhadap OCB dikarenakan nilai signifikansi kurang dari 0,05 .

Persamaan regresi yang dapat dibentuk dari tabel 9 diatas adalah:

$$
\mathrm{Y} 2=0,276 \mathrm{X} 1
$$

Melalui persamaan regresi tersebut dapat disimpulkan hal-hal sebagai serikut:

- Variabel Gaya Kepemimpinan Transformasional memberikan pengaruh yang positif dan signifikan terhadap OCB dengan koefisien Beta sebesar 0,276 atau $\beta 2$.

- Variabel Komitmen Organisasional tidak berpengaruh terhadap OCB 
Tabel 9

Koefisien Regresi Gaya Kepemimpinan Transformasional, Komitmen Organisasional dan OCB terhadap Kinerja

\begin{tabular}{|c|c|c|c|c|c|c|}
\hline Variabel & $\begin{array}{c}\text { Adj } \\
\text { R- } \\
\text { Square }\end{array}$ & $\begin{array}{c}\text { Hasil } \\
\text { Uji F }\end{array}$ & Sig & $\begin{array}{c}\text { Koefisien } \\
\text { Beta }\end{array}$ & $\begin{array}{c}\text { Hasil } \\
\text { t-Hitung }\end{array}$ & Sig \\
\hline $\begin{array}{c}\text { Komitmen } \\
\text { Organisasional }\end{array}$ & 0,411 & 24,719 & 0,00 & 0,299 & 2,709 & 0,008 \\
\hline $\begin{array}{c}\text { Kepemimpinan } \\
\text { Transformasional }\end{array}$ & & & & 0,128 & 1,143 & 0,256 \\
\hline OCB & & & 0,373 & 4,411 & 0,001 \\
\hline
\end{tabular}

Variabel Dependen: Kinerja

Sumber: Data primer yang diolah, 2014.

Hasil uji Adjusted $R$ Square $\left(\mathrm{R}^{2}\right)$ dari variabel Gaya Kepemimpinan Transformasional, Komitmen Organisasional, OCB terhadap variabel Kinerja adalah sebesar 0,411. Hal ini menunjukkan bahwa variabel Gaya Kepemimpinan Transformasional, Komitmen Organisasional dan OCB secara bersama-sama memberikan kontribusi sebesar 41,1\% terhadap variabel Kinerja . Dan berdasarkan Uji F diperoleh nilai F hitung sebesar 24,719 dengan signifikansi 0,00. Dari nilai tersebut dapat disimpulkan bahwa variabel Gaya Kepemimpinan Transformasional, Komitmen Organisasional dan OCB secara bersama-sama memberikan pengaruh yang positif dan signifikan terhadap Kinerja dikarenakan nilai Signifikansi kurang dari 0,05.

Persamaan regresi yang dapat dibentuk dari tabel 4.10 diatas adalah:

$$
\mathrm{Y} 3=0,299 \mathrm{Y} 1+0,373 \mathrm{Y} 2
$$

Melalui persamaan regresi tersebut dapat disimpulkan hal-hal sebagai berikut:

- Variabel Komitmen Organisasional memberikan pengaruh yang positif dan signifikan terhadap Kinerja dengan koefisien Beta sebesar 0,299.

- Variabel Kepemimpinan Transformasional tidak berpengaruh terhadap Kinerja dengan koefisien Beta sebesar 0,128.

- Variabel OCB memberikan pengaruh yang positif dan signifikan terhadap Kinerja dengan koefisien Beta sebesar 0,373 atau $\beta 6$.

\section{Uji Hipotesis (Uji t)}

\section{a. Uji Hipotesis I}

Hipotesis I berbunyi Gaya Kepemimpinan Transformasional berpengaruh positif dan signifikan terhadap Komitmen Organisasional. Berdasarkan Tabel 4.8 diketahui bahwa Gaya Kepemimpinan Transformasional mempunyai pengaruh positif dan signifikan terhadap Komitmen Organisasional, yang ditunjukkan oleh nilai signifikasi 0,00 nilai signifikasi kurang dari 0,05. Hasil ini membuktikan bahwa hiposesis yang menyatakan Gaya Kepemimpinan Transformasional berpengaruh positif terhadap komitmen organisasional pegawai Dinas Pertanian dan Kehutanan Kabupaten Rembang terbukti, sehingga hipotesis I diterima. 
b. Uji Hipotesis II

Hipotesis II berbunyi Gaya Kepemimpinan Transformasional berpengaruh positif dan signifikan terhadap OCB. Berdasarkan Tabel 4.9 diketahui bahwa Gaya Kepemimpinan Transformasional mempunyai pengaruh positif dan signifikan terhadap OCB, yang ditunjukkan oleh nilai signifikasi 0,035 nilai signifikasi kurang dari 0,05. Hasil ini membuktikan bahwa hiposesis yang menyatakan Gaya Kepemimpinan Transformasional berpengaruh positif terhadap OCB pegawai Dinas Pertanian dan Kehutanan Kabupaten Rembang terbukti, sehingga hipotesis II diterima.

c. Uji Hipotesis III

Hipotesis III berbunyi Komitmen Organisasional berpengaruh positif dan signifikan terhadap OCB. Berdasarkan Tabel 4.9 diketahui bahwa Komitmen Organisasional tidak signifikan terhadap OCB yang ditunjukkan oleh nilai signifikasi 0,131 nilai signifikasi lebih besar dari 0,05. Hasil ini membuktikan bahwa hiposesis yang menyatakan Komitmen Organisasional berpengaruh terhadap OCB pegawai Dinas Pertanian dan Kehutanan Kabupaten Rembang tidak terbukti, sehingga hipotesis III ditolak.

d. Uji Hipotesis IV

Hipotesis IV berbunyi Komitmen Organisasional berpengaruh positif dan signifikan terhadap Kinerja. Berdasarkan Tabel 4.10 diketahui bahwa Komitmen Organisasional pengaruh positif dan signifikan terhadap Kinerja yang ditunjukkan oleh nilai signifikasi 0,008 nilai signifikasi kurang dari 0,05. Hasil ini membuktikan bahwa hiposesis yang menyatakan Komitmen Organisasional berpengaruh terhadap Kinerja pegawai Dinas Pertanian dan Kehutanan Kabupaten Rembang terbukti, sehingga hipotesis IV diterima.

e. Uji Hipotesis V

Hipotesis V berbunyi Gaya Kepemimpinan Transformasional berpengaruh positif dan signifikan terhadap Kinerja. Berdasarkan Tabel 4.10 diketahui bahwa Gaya Kepemimpinan Transformasional tidak signifikan terhadap Kinerja yang ditunjukkan oleh nilai signifikasi 0,256 nilai signifikasi lebih besar dari 0,05. Hasil ini membuktikan bahwa hiposesis yang menyatakan Gaya Kepemimpinan Transformasional berpengaruh terhadap Kinerja pegawai Dinas Pertanian dan Kehutanan Kabupaten Rembang tidak terbukti, sehingga hipotesis V ditolak.

\section{f. Uji Hipotesis VI}

Hipotesis VI berbunyi OCB berpengaruh positif dan signifikan terhadap Kinerja. Berdasarkan Tabel 4.10 diketahui bahwa OCB pengaruh positif dan signifikan terhadap Kinerja yang ditunjukkan oleh nilai signifikasi 0,001 nilai signifikasi kurang dari 0,05. Hasil ini membuktikan bahwa hiposesis yang menyatakan OCB berpengaruh terhadap Kinerja pegawai Dinas Pertanian dan Kehutanan Kabupaten Rembang terbukti, sehingga hipotesis VI diterima.

\section{Uji Mediasi}

Mediasi merupakan variabel antara yang berfungsi memediasi hubungan antara variabel independen dengan variabel dependen. Untuk mengetahui efek mediasi dari suatu variabel intervening digunakan analisis jalur atau path analysis. Analisis jalur adalah penggunaan analisis regresi untuk menaksir hubungan kausalitas antar variabel yang telah ditetapkan sebelumnya berdasarkan teori. Apa yang dapat dilakukan oleh analisis jalur adalah 
menentukan pola hubungan antara 3 atau lebih variabel dan tidak dapat digunakan untuk mengkonfirmasi atau menolak hipotesis kasualitas imajiner (Ghozali, 2006). Dari model grafis dalam penelitian ini, terdapat 3 analisis jalur path sebagaimana berikut ini :

1) Komitmen Organisasional sebagai mediasi pengaruh Gaya Kepemimpinan Transformasional terhadap Kinerja Pegawai

Hubungan langsung variable Gaya Kepemimpinan Transformasional terhadap Kinerja ternyata tidak signifikan. Sedangkan hubungan tidak langsung signifikan, sehingga pengaruh Gaya Kepemimpinan Transformasional terhadap Kinerja dimediasi variable Komitmen Organisasional.

2) OCB sebagai mediasi pengaruh Gaya Kepemimpinan Transformasional terhadap Kinerja Pegawai

Hubungan langsung variable Gaya Kepemimpinan Transformasional terhadap Kinerja ternyata tidak signifikan. Sedangkan hubungan tidak langsung signifikan, sehingga pengaruh Gaya Kepemimpinan Transformasional terhadap Kinerja dimediasi variable OCB.

3) Komitmen Organisasional sebagai mediasi pengaruh Gaya Kepemimpinan Transformasional terhadap OCB

Hubungan variable Komitmen Organisasional terhadap OCB ternyata tidak signifikan karena signifikansinya sebesar 0,131 jauh di atas 0,05 . Dengan demikian dapat dikatakan bahwa variable Kepemimpinan Transformasional terhadap OCB dengan mediasi variable Komitmen Organisasional tidak bisa di uji

\section{Pembahasan}

\section{Deskripsi variabel Penelitian}

Deskripsi variabel penelitian di dalam penelitian ini dikategorikan dalam 7 (tujuh) tingkat jawaban, yang tersusun kategori variabel sebagai berikut: sangat setuju ( $\mathrm{SS}=7$ ), setuju $(\mathrm{S}=6)$, agak setuju ( $\mathrm{AS}=5$ ), netral $(\mathrm{N}=4)$, agak tidak setuju (ATS=3), dan sangat tidak setuju (STS=1). Pada analisis pendapat responden diukur dengan tujuh skala tersebut guna mengetahui derajat kesetujuan dan ketidaksetujuan responden terdapat serangkaian pernyataan. Adapun analisis ini sebagai berikut :

a.Variabel gaya kepemimpinan transformasional

Dari variabel gaya kepemimpinan transformasional menunjukkkan mode frekuensi observasi 6 (enam) yang sering muncul dari 12 indikator adalah jawaban setuju. Ini bermakna bahwa pegawai di Dinas Pertanian dan Kehutanan Kabupaten Rembang, mempersepsikan kepemimpinan sudah baik meskipun masih terdapat kekurangan seperti kepercayaan kepada atasan, atasan sebagai simbul kesuksesan, motivasi dari sesama,mendapat penghargaan kalau kerja dengan baik. Beberapa responden memberikan jawaban tidak setuju untuk indikator tersebut meskipun porsinya relatif kecil.

Nilai rata-rata (Mean) skor tertinggi dari 12 indikator variabel gaya kepemimpinan yaitu indikator optimisme bawahan $(6,10)$ hal ini menandakan bahwa pimpinan mempercayahi bawahannya dalam melaksanakan tugas. Sedangkan skor rata-rata terendah adalah indikator atasan sebagai simbul kesuksesan $(5,03)$. Hal ini menandakan bahwa responden menganggap sukses organisasi tidak tergantung pada pimpinan saja. 
b. Variabel Komitmen Organisasional

Dari variabel Komitmen Organisasional menunjukkkan mode frekuensi observasi 6 (enam) yang sering muncul dari 24 indikator adalah jawaban setuju. Ini bermakna bahwa pegawai di Dinas Pertanian dan Kehutanan Kabupaten Rembang, mempersepsikan komitmen organisasional sudah baik meskipun masih terdapat kekurangan seperti menghabiskan sisa karier di organisasi, bangga pada organisasi, masalah organisasi, tidak terikat pada organisasi, emosional, organisasi memiliki arti yang sangat besar, perasaan takut berhenti dari pekerjaan, sulit meninggalkan organisasi, banyak hal terganggu di organisasi, kerugian besar jika meninggalkan organisasi, bekerja merupakan kebutuhan, memiliki sedikit pilihan, perasaan tidak mungkin meninggalkan organisasi, melanjutkan pekerjaan, sering pindah organisasi, loyal pada organisasi, pindah organisasi adalah tidak etis, pentingnya loyalitas, tawaran pindah. Beberapa responden memberikan jawaban tidak setuju untuk indikator tersebut meskipun porsinya relatif kecil.

Nilai rata-rata (Mean) skor tertinggi dari 24 indikator variabel Komitmen Organisasional yaitu indikator menekuni pekerjaan $(6,03)$ hal ini menandakan bahwa responden tekun dalam melaksanakan tugas di organisasi. Sedangkan skor rata-rata terendah adalah indikator banyak hal terganggu (4,16). Hal ini menandakan bahwa responden menganggap di organisasi bekerja tidak ada hal yang mengganggu dalam menyelesaikan tugas.

\section{c. Variabel OCB}

Dari variabel OCB menunjukkkan mode frekuensi observasi 6 (enam) yang sering muncul dari 17 indikator adalah jawaban setuju. Ini bermakna bahwa pegawai di Dinas Pertanian dan Kehutanan Kabupaten Rembang, mempersepsikan OCB sudah baik meskipun masih terdapat kekurangan seperti tidak pernah membolos, sukarela melaksanakan tugas ekstra, bersedia mengikuti pelatihan tambahan. Beberapa responden memberikan jawaban tidak setuju untuk indikator tersebut meskipun porsinya relatif kecil.

Nilai rata-rata (Mean) skor tertinggi dari 17 indikator variabel OCB yaitu indikator tidak memaksakan kehendak atas ide-ide yang disampaikan $(6,36)$ hal ini menandakan bahwa responden merasa bebas menyampaikan ide-idenya Sedangkan skor rata-rata terendah adalah indikator bersedia mengikuti pelatihan $(5,19)$. Hal ini menandakan bahwa responden mengganggap pelatihan kurang penting disebabkan menyita waktu tugas harian.

\section{d. Variabel Kinerja}

Dari variabel kinerja menunjukkkan mode frekuensi observasi 6 (enam) yang sering muncul dari 11 indikator adalah jawaban setuju. Ini bermakna bahwa pegawai di Dinas Pertanian dan Kehutanan Kabupaten Rembang, mempersepsikan kinerja sudah baik meskipun masih terdapat kekurangan seperti distribusi pekerjaan. Beberapa responden memberikan jawaban tidak setuju untuk indikator tersebut meskipun porsinya relatif kecil.

Nilai rata-rata (Mean) skor tertinggi dari 11 indikator variabel kinerja yaitu indikator kepatuhan kerja $(6,15)$ hal ini menandakan bahwa responden patuh pada aturan yang ada di Dinas Pertanian dan Kehutanan Kabupaten Rembang Sedangkan skor rata-rata terendah adalah indikator distribusi pekerjaan $(5,55)$. Hal ini menandakan bahwa responden mengganggap distribusi pekerjaan yang ada kurang seimbang.

\section{Deskripsi Uji Hipotesis}

\section{a. Hipotesis I}

Hipotesis pertama dapat diterima, hal ini berarti mendukung penelitian terdahulu yang dilakukan oleh Kaihatu dan Rini (2007) yang menyatakan bahwa kepemimpinan transformasional memiliki pengaruh positif dan signifikan terhadap Komitmen Organisasional. Terbuktinya hipotesis ini dapat dinyatakan jika Gaya 
Kepemimpinan di lingkungan Dinas Pertanian dan Kehutanan Kabupaten Rembang, dikaitkan dengan Komitmen Organisasional, maka seorang pemimpin harus mampu memotivasi bawahan dengan mengembangkan visi dan misi organisasi dan memaksimalkan potensi pegawai sehingga meningkatkan komitmen secara optimal.

b. Hipotesis II

Hipotesis kedua dapat diterima, hal ini berarti mendukung penelitian terdahulu yang dilakukan oleh Lamidi (2008) yang menyatakan bahwa kepemimpinan transformasional memiliki pengaruh positif dan signifikan terhadap OCB. Terbuktinya hipotesis ini dapat dinyatakan jika Gaya Kepemimpinan di lingkungan Dinas Pertanian dan Kehutanan Kabupaten Rembang, dikaitkan dengan OCB, maka seorang pemimpin harus mampu memberi petunjuk bawahan dalam bekerja sehingga meningkatkan kinerja..

c. Hipotesis III

Hipotesis ketiga ditolak, hal ini mendukung hasil penelitian yang dilakukan oleh Darmawati, Hidayati, dan Herlina S (2013) yang menyatakan bahwa Komitmen Organisasional memiliki pengaruh negatif dan tidak signifikan terhadap OCB pada karyawan Fakultas Ilmu Sosial dan Ekonomi Universitas Negeri Yogyakarta.

Karyawan yang ada pada Dinas Pertanian dan Kehutanan sebagian besar tenaga teknis yang ada di lapangan sehingga komitmen terhadap organisasi dinilai masih kurang, karena mereka bisa bertahan diluar organisasi untuk melaksanakan kewajibannya. OCB merupakan perilaku yang melebihi apa yang distandarkan karyawan, sehingga komitmen yang tinggi tidak selalu menyebabkan seorang melakukan OCB.

\section{d. Hipotesis IV}

Hipotesis keempat diterima, hal ini mendukung hasil penelitian yang dilakukan oleh Fakhrizal, Yunus, Amri (2012) yang menyatakan bahwa komitmen organisasional berpengaruh positif dan signifikan terhadap kinerja Dinas Pengelolaan Keuangan dan Kekayaan Aceh. Terbuktinya hipotesis ini dapat dinyatakan jika Komitmen Organisasional di lingkungan Dinas Pertanian dan Kehutanan Kabupaten Rembang, dikaitkan dengan Kinerja Pegawai, maka seorang pegawai selalu menekuni pekerjaan yang diterima dan loyal di organisasi sehingga meningkatkan kinerja.

\section{e. Hipotesis V}

Hipotesis kelima ditolak, hal ini tidak mendukung hasil penelitian yang dilakukan oleh Marjam (2010) yang menyatakan bahwa gaya kepemimpinan transformasional berpengaruh positif dan signifikan terhadap kinerja pegawai pada Dinas Pendidikan Kabupaten Sukoharjo. Terbuktinya hipotesis ini dapat dinyatakan jika kepemimpinan, di lingkungan Dinas Pertanian dan Kehutanan Kabupaten Rembang, dikaitkan dengan kinerja pegawai, maka seorang pemimpin harus dapat menjadi simbol keberhasilan dan prestasi bagi pegawainya, selain itu pemimpin harus pula mendistribusi pekerjaan secara merata dan berimbang sesuai dengan kapasitas pegawai, pemimpin selalu memberi saran, petunjuk dan arahan kepada bawahan dalam menyelesaikan pekerjaan, pemimpin dapat memberikan penghargaan kepada bawahan yang dapat menyelesaikan pekerjaan dengan baik. Pegawai lebih baik dikasih pelatihan sehingga mampu bekerja lebih cepat dan tepat. 


\section{f. Hipotesis VI}

Hipotesis keenam dapat diterima, hal ini berarti mendukung hasil penelitian yang dilakukan oleh Linda Kartini Ticoalu (2013), yang menyatakan bahwa OCB berpengaruh positif dan signifikan terhadap kinerja pegawai pada PT Bank Tabungan Pensiunan Nasional (BPTPN). Terbuktinya hipotesis ini dapat dinyatakan jika OCB di lingkungan Dinas Pertanian dan Kehutanan Kabupaten Rembang, dikaitkan dengan Kinerja Pegawai, maka seorang pegawai selalu membantu rekan kerja yang memiliki masalah dalam menyelesaikan tugas, pegawai selalu tepat waktu dalam menyelesaikan tugas, tidak suka mengeluh dalam melaksanakan tugasnya sehingga perilaku pegawai ini bisa meningkatkan kinerja.

\section{Kesimpulan, Saran, Keterbatasan, dan Rekomendasi}

\section{Kesimpulan}

Berdasarkan hasil analisis data mengenai peran karakteristik individu dan karakteristik pekerjaan terhadap kinerja pegawai Dinas Pertanian dan Kehutanan Kabupaten Rembang melalui komitmen organisasional dan OCB sebagaimana telah dijelaskan pada bab sebelumnya, maka penulis dapat mengambil kesimpulan sebagai berikut :

1. Berdasarkan hasil hipotesis 1 secara parsial diketahui bahwa gaya kepemimpinan transformasional berpengaruh positif dan signifikan terhadap komitmen organisasional di Dinas Pertanian dan Kehutanan Kabupaten Rembang. Hasil ini memberi arti bahwa gaya kepemimpinan yang dimiliki oleh pimpinan pada Dinas Pertanian dan Kehutanan Kabupaten Rembang ternyata mampu mempengaruhi perubahan positif terhadap komitmen organisasional.

2. Berdasarkan hasil hipotesis 2 secara parsial diketahui bahwa gaya kepemimpinan transformasional berpengaruh positif dan signifikan terhadap OCB pegawai Dinas Pertanian dan Kehutanan Kabupaten Rembang. Hasil ini memberi arti bahwa gaya kepemimpinan yang dimiliki oleh pimpinan pada Dinas Pertanian dan Kehutanan Kabupaten Rembang ternyata mampu mempengaruhi perubahan positif terhadap perilaku pegawai.

3. Berdasarkan hasil hipotesis 3 secara parsial diketahui bahwa komitmen organisasional tidak berpengaruh terhadap OCB pegawai Dinas Pertanian dan Kehutanan Kabupaten Rembang. Hasil ini memberi arti bahwa komitmen organisasional yang ada di Dinas Pertanian dan Kehutanan Kabupaten Rembang ternyata tidak mampu mempengaruhi perubahan positif terhadap OCB pegawai.

4. Berdasarkan hasil hipotesis 4 secara parsial diketahui bahwa komitmen organisasional tidak berpengaruh terhadap kinerja pegawai Dinas Pertanian dan Kehutanan Kabupaten Rembang. Hasil ini memberi arti bahwa komitmen organisasional yang ada di Dinas Pertanian dan Kehutanan Kabupaten Rembang ternyata tidak mampu mempengaruhi perubahan positif terhadap kinerja pegawai.

5. Berdasarkan hasil hipotesis 5 secara parsial diketahui bahwa gaya kepemimpinan transformasional tidak berpengaruh terhadap kinerja pegawai Dinas Pertanian dan Kehutanan Kabupaten Rembang. Hasil ini memberi arti bahwa gaya kepemimpinan yang dimiliki oleh pimpinan pada Dinas Pertanian dan Kehutanan Kabupaten Rembang ternyata tidak mampu mempengaruhi perubahan positif terhadap kinerja pegawai.

6. Berdasarkan hasil hipotesis 6 secara parsial diketahui bahwa OCB berpengaruh positif dan signifikan terhadap kinerja pegawai Dinas Pertanian dan Kehutanan Kabupaten Rembang. Hasil ini memberi arti bahwa perilaku pegawai yang ada di Dinas Pertanian 
dan Kehutanan Kabupaten Rembang ternyata mampu mempengaruhi perubahan positif terhadap kinerja pegawai.

7. Variabel komitmen organisasional menjadi variabel mediasi pengaruh kepemimpinan transformasional terhadap kinerja pegawai. Hasil ini memberi arti bahwa komitmen organisasional yang ada di Dinas Pertanian dan Kehutanan Kabupaten Rembang ternyata mampu memediasi sempurna kepemimpinan transformasional terhadap kinerja pegawai.

8. Variabel OCB menjadi variabel mediasi pengaruh kepemimpinan transformasional terhadap kinerja pegawai. Hasil ini memberi arti bahwa OCB yang ada di Dinas Pertanian dan Kehutanan Kabupaten Rembang ternyata mampu memediasi sempurna kepemimpinan tranformasional terhadap kinerja pegawai.

\section{Saran}

Beberapa saran yang dapat penulis sampaikan berdasarkan kesimpulan dan keterbatasan dalam penelitian ini adalah :

1. Pegawai akan meningkat kinerjanya apabila pemimpin tidak sebagai simbol kesuksesan, pemimpin bisa menjelaskan tujuan pekerjaan, menunjukkan cara baru menyelesaikan masalah, pemimpin menggunakan penalaran dalam bekerja.

2. Berdasarkan Hasil Uji Regresi diketahui bahwa kepemimpinan transformasional berpengaruh secara langsung terhadap kinerja sehingga untuk meningkatkan kinerja pegawai Dinas Pertanian dan Kehutanan Kabupaten Rembang. Penerapan kepemimpinan transformasional yang semakin efektif, ditunjukkan dari kepuasan kerja dan kepercayaan bawahan yang semakin tinggi, loyalitas dan rasa hormat kepada atasan.

3. Pada dasarnya secara organisasional komitmen karyawan dapat dipengaruhi oleh berbagai faktor, salah satunya melalui perilaku kepemimpinan.

\section{Keterbatasan}

Dalam penelitian ini, permasalahan hanya dibatasi pada variabel gaya kepemimpinan transformasional, Komitmen organisasional, organizational citizenship behavior (OCB), dan Kinerja.

Penelitian ini juga terbatas pada obyek pengamatan yang sempit, yaitu hanya dibatasi pada Dinas Pertanian dan Kehutanan Kabupaten Rembang, dimana sampel yang diteliti yang diambil dengan metode sensus mengingat populasi yang terbatas.

\section{Rekomendasi Penelitian Mendatang}

Rekomendasi untuk penelitian yang akan datang dapat penulis sampaikan berdasarkan kesimpulan dan keterbatasan dalam penelitian ini adalah :

1. Perlu dilakukan penelitian lain atau lanjutan dengan memasukkan variabelvariabel lain misalkan variabel kepemimpinan transformasional, analisis beban kerja dan sebagai variabel yang kemungkinan juga berpengaruh terhadap kinerja pegawai.

2. Mengembangkan populasi dengan wilayah yang lebih luas sehingga lebih dalam dalam melakukan pembahasan dalam penelitian yang tidak hanya terbatas pada wilayah Kabupaten Rembang.

3. Melakukan pengambilan sampel dengan membatasi tingkat beban kerja sehingga dapat diketahui perbedaan yang lebih signifikan antara staf dan atasan. 


\section{Daftar Pustaka}

Allen,N.J. and Meyer, J.P. 1991. A Three-Component Conceptualization of Organizational Commitment, Human Resource Management Review, Vol 1, No 1, pp. 61-89.

Antonakis,J., Avolio,B.J., and Sivasubramaniam, N. 2003. Context and Leadership : An Examination of the Nine Factor Full-Range Leadership Theory Using the Multifactor Leadership Questionnaire, The Leadership Quarterty, Vol 14, No 2, pp. 261-295.

Arum Darmawati, Lina Nur Hidayati, dan Dyna Herlina S, 2013. Pengaruh Kepuasan Kerja dan Komitmen Organisasi terhadap Organizational Citizenship Behavior (OCB), “Jurnal Economia” Vol 9, No 1.

Aydogdu,S., and Asikgil, B. 2011. An Empirical Study of the Relationship Among Job Satisfaction, Organizational Commitment and Turnover Intention, International review of Management and Marketing, Vol 1, No 3, pp. 43-53.

Bolon, D.S. 1997. Organizational citizenship behavior among hospital employees: A Multidimensional Analysis Involving Job Satisfaction and Organizational Commitment, Hospital \& Health Services Administration,, Vol 42, No 42, No 2, pp 221-241.

Cavazotte, F., Moreno, V., Hickmann, M. 2012. Effects of Leader Intelligence, Personality and Emotional Intelligence on Transformational Leadership and Managerial Performance, The Leadership Quarterly, Vol 23, pp. 443-455. Greenberg, j. Wright, D. 2001. Retaining employees - the fast track to commitment, Management Research News, Vol 24, No 8, pp. 59-64.

Curtis, S., and W, (1984), Organization and Environment, Homewood, IL : Richard D. Irwin.

Curtis, S., and Wright, D. 2001. Retaining Employees - The Fast Track to Commitment, Management Research News, Vol 24, No 8, pp. 59-64.

Greenberg, j. Wright, D. 2001. Retaining employees - the fast track to commitment, Management Research News, Vol 24, No 8, pp. 59-64.

Debora Eflina Purba dan Ali Nina Liche Seniati, 2004. Pengaruh Kepribadian dan Komitmen Organisasi terhadap Organizational Citizenship Behavior (OCB), "Makara, Sosial, Humaniora" Vol 8, No 3, pp. 105-111

Dessler,G, 2000, Human Resource Management 8 th edition, New Jersey : Prentice Hall inc.

Durkin,M., and Bennet, H, 1999. Employee Commitment in Retail Banking: Identifying and Exploring Hidden Dangers, The International Journal of Bank Marketing, Vol 17, No 3, pp. 124-137.

Ferdinand, A. 2002, Structural Equation Modelling dalam Penelitian Manajemen. Semarang: BP UNDIP. 
Gibson, J.L., Ivancevich, J.M., Donnelly Jr. 2009. Organisasi: Perilaku, Struktur, Proses, Edisi Bahasa Indonesia, Tangerang: Binarupa Aksara.

Goodwin, V.L., Wofford, J.C., and Whittington, J.L. 2001. A Theoretical and Empirical Extension to the Transformational Leadership Construct, . Journal of Organizational Behavior, Vol 22, No 7, pp. 759-774.

Ghozali, Imam, 2009, Aplikasi Analisis Multivariat dengan Program IBM SPSS 20, Badan Penerbit UNDIP. Semarang

Handoko, Hani, 2002, Manajemen Personalia dan Sumber Daya Manusia, BPFE. Yogyakarta.

Huang, C.C., You, C.S., and Tsai, M.T.2012. A Multidimensional Analysis of Ethical Climate, Job Satisfaction, Organizational Commitment, and Organizational Citizenship Behaviors, Nursing Ethics, Edisi Ketujuh, Jakarta: Salemba Humanika.

Hughes, R.L., Ginnett, R.C and Curphy, G.J. 2012. Leadership: Memperkaya Pelajaran dari Pengalaman, Edisi Ketujuh, Jakarta: Salemba Humanika.

John, M.C., and Taylor J.W. 1999. Leadership Style, School Climate, and the Institutional Commitment of Teachers. International Forum Vol 2, No 1, pp. 25-57.

Karakus, M., and Aslan, B. 2008. Teachers' commitment focuses: a three-dimensioned view, Journal of Management Development, Vol 28, No 5, pp. 425-438.

Khuntia, R., and Suar, D. 2004. A Scale to Assess Ethical Leadership of Indian Private and Public Sector Managers, Journal of Business Ethies, Vol 49, No 1, pp. 13-26.

Krishnan R., Arumugam, N., Chandran, V., and Kanchymalay, K. 2009. Examining the Relationship between Job Satisfaction and Organizational Citizenship Behavior: A Case Study among Non Academic Staffs in A Public Higher Learning Institution in Malaysia, Global Business Summit Conference, Vol 2, No 43,pp. 221-232

Kumar, K., Bakhshi, A., and Rani, E. 2009. Linking the 'Big Five' Personality Domains to Organizational Citizenship Behavior, International Journal of Psychological Studies, Vol 1, No 2, pp. 73-81.

Lamidi, 2008. Pengaruh Kepemimpinan Transformasional terhadap Organizational Citizenship Behavior: dengan Variabel Intervening Komitmen Organisasional, “Jurnal Ekonomi dan Kewirausahaan” Vol 8, No 1, pp. 25-37.

Linda Kartini Ticoalu, 2013. Organizational Citizenship Behavior (OCB) dan Komitmen Organisasi Pengaruhnya terhadap Kinerja Karyawan, "Jurnal EMBA" Vol 1, No 4, pp. $782-790$.

Luthans, F. 2006, Perilaku Organisasi, Edisi Sepuluh, Yogyakarta: Penerbit Andi. 
MacKenzie, S.B., Podsakoff, P.M., and Ahearne, M. 1998. Some Possible Antecedents and Consequences of In-Role and Extra-Role Salesperson Performance The Journal of Marketing, Vol 62, No 3, pp. 87-98.

Marjam Desma Rahadhini, 2010. Efek Moderasi Budaya Organisasi pada Pengaruh Kepemimpinan Transformasional terhadap Kinerja Pegawai, "Jurnal Manajemen Sumberdaya Manusia” Vol 4, No 1, pp. 20-26.

Marita Ahdiyana, 2010. Dimensi Organizational Citizenship Behavior (OCB) dalam Kinerja Organisasi, “Jurnal Efisiensi” Vol X, ISSN; 1412-1131.

Meyer, J.P., Stanley, D.J., Herscovitch, L., and Topolnytsky, L. 2002. Affective, Continuance, and Normative Commitment to the Organization: A Meta analysis of Antecedents, Correlates, and Consequences, Journal of Vocational Behavior, Vol 61, pp. 20-52.

Nurul Fakhrizal, Mukhlis Yunus, dan Amri, 2012. Pengaruh Komitmen Individu, Organisasi dan Gaya Kepemimpinan terhadap Kinerja Pegawai serta Dampaknya pada Kinerja Dinas Pengelolaan Keuangan dan Kekayaan Aceh, "Jurnal Manajemen Pascasarjana Universitas Syiah Kuala” Vol 2, No 1, pp. 68-84

Nguni, S.C., 2005. A Study of the Effects of Transformational Leadership on Teachers Job Satisfaction, Organizational Commitment and Organizational Citizenship Behaviour in Tanzanian Primary and Secondary Schools, Doctoral thesis, Universiteit Nijmegen.

Organ, D.W., Podsakoff, P.M., and MacKenzie, S.B. 2006, Organizational Citizenship Behavior: Its Nature, Antecedents, and Consequences, SAGE Publications.

Podsakoff, P.M., MacKenzie, S.B., Paine, J.B., and Bachrach, D.G. 2000. Organizational Citizenship Behaviors: A Critical Review of the Theoretical and Empirical Literature and Suggestions for Future Research, Journal of Management, Vol 26, No 3, pp. 513563.

Rivai, V., dan Mulyadi. D. 2012, Kepemimpinan dan Perilaku Organisasi, Jakarta: Rajawali Pers.

Robbins, S.P., and Judge, T.A. 2008, Perilaku Organisasi. Edisi Kedua belas, Jakarta: Salemba Empat.

Shweta, J., and Srirang, J. 2010. Determinants of Organizational Citizenship Behavior: A Review of Literature, Journal of Management and Public Policy, Jakarta : Vol 1, No 2, pp. 27-36.

Sopiah, 2008, Perilaku Organisasional, Yogyakarta: Penerbit Andi.

Siagian, S.P., 1995. Teori Motivasi dan Aplikasinya, Jakarta: Rineke Cipta.

Tett, R.P., and Meyer, J.P. 1993. Job Satisfaction, Organizational Commitment, Turnover Intention, and Turnover: Path Analyses Based on Meta-Analytical Findings, Personnel Psychology, Vol 1, No 1, pp. 35-49. 
Prima Kartika Sari

Euis Soliha
Jurnal Manajemen Bisnis Indonesia

Vol. 3, Nomor 3, Juni 2016

Thomas Stefanus Kaihatu, 2007. Kepemimpinan Transformasional dan Pengaruhnya terhadap Kepuasan atas Kualitas Kehidupan Kerja, Komitmen Organisasi, dan Perilaku Ekstra Peran: Studi pada Guru-Guru SMU di Kota Surabaya, "Jurnal Manajemen dan Kewirausahaan" Vol 98, No 1, pp. 49-61.

Yukl, G. 2010, Kepemimpinan dalam Organisasi, Edisi Indonesia. Jakarta: Penerbit PT Indeks. 